\title{
Édipo e Jó na África Ocidental
}

Meyer Fortes. Oedipus and Job in West African Religion (with an essay by Robin Horton), Cambridge, Cambridge University Press, 1983.

\author{
Tradução de Samuel Titan Jr. \\ Mestrando em Teoria Literária pela USP \\ $e$ bolsista do CNPq. \\ Colaborador da Folha de S. Paulo e de \\ vários periódicos especializados.
}

\section{A noção de Destino segundo Frazer}

Alguém já disse que há dois tipos de poetas. Há os que escrevem para outros poetas, tal como há os que escrevem para o leitor comum. Os antropólogos podem ser classificados de maneira semelhante. Há os puristas por convicção ou por hábito, que escrevem exclusivamente para seus pares profissionais, assim como existem os antropólogos do fórum ou da praça pública, que se dirigem aos leitores em geral. Mas há também aqueles que parecem igualmente à vontade em ambos os mundos, e entre esses Sir James George Frazer não teve e não tem rivais. Sua influência sobre o pensamento progressista de seu tempo já é proverbial, e seus escritos ainda gozam de um respeito próximo ao terror sagrado fora do ambiente antropológico profissional. De onde deriva, então, o recente declínio de sua influência entre seus sucessores na profissão? Creio que isto se deve principalmente ao fato de Frazer não ter sido apenas um grande antropólogo e homem de letras, mas também um moralista, cujo empenho em expandir as luzes prevaleceu demasiado freqüentemente sobre seu juízos acadêmicos. Sua prosa brilhante oculta muitas conjecturas apressadas; hipóteses expostas com enorme erudição acabam por se revelar pouco mais que rótulos descritivos de costumes e instituições; e as especulações históricas e psicológicas usadas para arrimá-las parecem ingênuas hoje em dia. Desagrada-nos o desprezo presunçoso por crenças e costumes exóticos, apresentados com íntimo deleite e depreciativamente contrastados com o "espírito civilizado". A antropologia moderna partiu de Frazer, mas teve igualmente que se apartar dele. 
No entanto, cedo ou tarde, todo antropólogo sério retorna ao grande corpus frazeriano. Pois sob as incrustações de teoria, especulação e preconceito, devidas ao clima intelectual em que viveu Frazer, há uma visão do homem que ainda pode trazer inspiração. Sua grandeza está em abranger o conjunto da humanidade. Mostrase aí em detalhe quão vários e diversos podem ser os costumes e instituições humanos, ao mesmo tempo em que se procura apontar para a unidade atrás da diversidade. Para Frazer, essa unidade residia em certas conexões históricas, bem como em hábitos e disposições mentais comuns. Por falaciosas que se mostrem suas teorias hoje em dia, em princípio ele estava correto. Existem uniformidades e padrões comuns nas instituições humanas, e se quisermos entendê-los, teremos que levar em conta as disposições emocionais e intelectuais comuns a toda a humanidade.

Frazer não acharia estranho colocar lado a lado Édipo, Jó e as crenças religiosas de uma tribo da África Ocidental voltadas para o culto dos ancestrais, tal como proponho fazer. Mas quando se punha a empilhar os costumes de gregos, hebreus, outros povos da antigüidade clássica, sociedades primitivas ainda existentes e sociedades orientais, Frazer interessava-se por seus traços descritivos mais superficiais. Tomemos um exemplo ao acaso: Orestes, o matricida que recupera a sanidade mental arrancando com os dentes um de seus dedos, é citado numa série de casos sobre vingadores de homicídios entre indígenas americanos, maoris e africanos que devem provar o sangue de suas vítimas a fim de apaziguar seus fantasmas ${ }^{1}$. Isto é o que nos explicam nossos informantes; mas, do ponto de vista atual, seria absurdo ver estes costumes simplesmente como expressões distintas de um medo de fantasmas agindo como freio para assassinos potenciais. O que é significativo para nós na história de Orestes é que ele tenha assassinado uma parente sua, que essa parente fosse sua mãe, e que sua expiação tenha consistido em arrancar a mordidas um dedo seu. Teria sido tolo chegar a tal extremo apenas pelo gosto de experimentar o próprio sangue. Os paralelos que prontamente ocorrem ao antropólogo contemporâneo são automutilações semelhantes e aparentemente irracionais, levadas a cabo no contexto de um conflito de gerações sucessivas, seja ele aberto ou camuflado. Pensamos na estranha história de Séfora (Ziporah), a esposa de Moisés que circuncisa seu filho com uma pedra de sílex a fim de evitar que Yahweh o mate ${ }^{2}$, ou então, mais particularmente, na difundida associação entre a circuncisão (e outras formas de mutilação) e a iniciação de rapazes e moças na vida adulta.

Em suma, deveríamos utilizar a história de Orestes não para ilustrar uma dada espécie de superstição bárbara, mas sim como um modelo, um paradigma, a partir do qual poderíamos derivar princípios aplicáveis a outros casos.

Do mesmo modo, tanto Édipo quanto Jó figuram na obra de Frazer sobre o Folclore no Antigo Testamento tão-somente para ilustrar certos costumes "supersticiosos" muito difundidos. Jó é citado, bem curiosamente, em apoio à afirmação de que, no Antigo Testamento, o sangue de um homem assassinado, e não seu 
fantasma, é que clama por vingança - como quando Jó "apela contra a injustiça de seu destino (...) 'Ó terra, não cubras meu sangue, nem encontre meu clamor um lugar de descanso' "'. Quanto a Édipo, ele aparece como paralelo à história de Moisés no berço entre os juncos. Ele é um dos muitos exemplos do herói "abandonado ao nascer e resgatado da morte iminente por meios que o vulgo tomaria por acidentais, mas que se revelam como a mão do Destino que intervém a fim de preservar a criança para o grande destino que lhe está reservado (...)"’4.

O Destino - ou Fado - é o tema central deste ensaio. Frazer menciona-o em várias passagens de seus escritos, e invariavelmente da maneira que descrevi. Não há qualquer tentativa de analisar a noção de Destino enquanto uma categoria do pensamento religioso ou filosófico. A noção é tratada como qualquer outra crença tradicional - uma crença em fantasmas, presságios aziagos ou encantamentos mágicos para afugentar ameaças sobrenaturais.

Consideremos as histórias de Édipo e Jó de um ponto de vista mais analítico do que descritivo ${ }^{5}$. O que é notável então é o modo como as duas exemplificam, de modo comovente e dramático, duas concepções éticas e religiosas que parecem mutuamente opostas sob alguns aspectos e complementares sob outros. Essas idéias estão associadas a doutrinas cosmológicas distintas sobre a natureza do homem e sua relação com os poderes sobrenaturais. Penso que elas representam, clara e paradigmaticamente, dois princípios fundamentais do pensamento e dos costumes religiosos. O princípio edípico é bem resumido pela noção de Destino ou Fado, enquanto o princípio de Jó é captado pela noção de Justiça Sobrenatural.

Não estou sugerindo que o conjunto do sistema religioso da Grécia no século V a.C. possa ser reduzido ao que consta da história de Édipo, ou que no drama de Jó esteja contida toda a religião hebraica do Antigo Testamento. Ocupome apenas das concepções específicas encarnadas nas duas histórias. Seu caráter religioso é admitido por todas as autoridades no assunto ${ }^{6}$, e o que desejo mostrar é como também ocorrem em sistemas religiosos da África Ocidental.

\section{2 ÉdiPo E Jó COMO PARAdIGMAS}

O mito de Édipo nos é mais familiar na versão da trilogia tebana de Sófocles, e o que dá a essas peças sua intensidade trágica não é o terror que elas despertam frente ao parricídio e ao incesto, mas sim, como nota o Sr. Lucas, o "sentimento de cegueira e impotência da humanidade" que transmitem. A catástrofe que esmaga Édipo é devida, acrescenta o mesmo comentador, a causas "profundamente ocultas na natureza dos deuses e dos homens", e não a qualquer erro do protagonista. Pelo contrário: Édipo é um homem de caráter nobre e virtuoso, que prefere o auto-exílio ao risco de matar seu suposto pai; é um rei benevolente, marido fiel e pai devotado. Ele tem mesmo uma qualidade a mais, que acabará por 
causar sua ruína: ele busca resolutamente a verdade. Quando descobre a história de seu nascimento e seu matrimônio, ele não tem como não cegar a si mesmo, para assim afastar a verdade insuportável e poder continuar vivendo. Seus pecados são tão infames que nem mesmo a morte poderia expiá-los.

Mas a questão não está apenas no fato de Édipo cometê-los inadvertidamente: suas ações parecem impor-se a ele, como se fosse forçado a cometê-las por uma força operando fora do alcance do conhecimento humano, indiferente à conduta humana. Ele é uma vítima do Destino. O problema de sua responsabilidade e sua culpa sequer parecem relevantes. A questão ressurge mais tarde, no Édipo em Colono, quando o velho Édipo se prepara para a morte e afirma sua inocência: tudo fora obra do Destino terrível, e não fruto de decisões suas.

O papel desempenhado pelo conceito de Destino - tradução costumeira do grego Moira - na religião grega arcaica foi muito discutido pelos estudiosos clássicos ${ }^{8}$ Certamente era uma noção muito complexa, mas nossas autoridades parecem concordar que seu significado original era o de "porção" ou "quinhão". Além disso, parece ter tido dois aspectos principais. Um era a idéia de Destino enquanto força impessoal que representava a necessidade e a justiça de uma "disposição da Natureza" - como escreve o professor Dodds - superior a deuses e homens. O outro aspecto referia-se ao indivíduo: acreditava-se que a cada pessoa era reservada, desde o nascimento, uma certa quantidade de bens e males para o resto da vida. E essa sorte, citando outra vez o professor Dodds, "não é tomada como um acidente extraordinário, é parte dos dotes naturais de cada indivíduo, tal como sua beleza ou seus talentos". Este é o aspecto mais notável do mito de Édipo. Mas por aí percebemos ainda que o destino do indivíduo é parcialmente determinado pelo de seus pais, e que ele próprio afetará o destino de seus descendentes. O professor Dodds relaciona isto à idéia - familiar para os antropólogos, dada a sua ocorrência em muitas sociedades primitivas - de que a vida do filho é um "prolongamento da vida de seu pai”. Pelas leis de filiação e descendência, um filho que herda a posição social de seu pai herda ipso facto todas as suas propriedades e débitos, materiais como espirituais. Entretanto, a sucessão costuma ser um ato deliberado e voluntário, a não ser que o Destino se intromete, como aconteceu com Édipo, e a sucessão se faça por uma compulsão cega, frente à qual é vã a resistência.

Há aqui uma semelhança entre as noções de Destino e bruxaria ${ }^{10}$. O Destino, como a bruxaria, é uma força involuntária que, em última análise, só pode ser reconhecida retrospectivamente. Isso basta por si só para motivar o apelo a oráculos. Mas os oráculos não permitem aos homens o controle efetivo do Destino. Tal como acontece com a bruxaria, eles podem apenas ajudar a promover uma reconciliação com o inelutável. Parece melhor aceitar o Destino a continuar provocando-o.

Jó nos confronta com uma concepção inteiramente distinta do homem e da vida mortal. Não há qualquer indicação de influências inescrutáveis regendo o curso da 
vida humana a partir do instante do nascimento. $O$ bem e o mal que advêm a cada homem são recompensas e castigos fixados por um Deus onipotente e personificado. Mas Deus não age arbitrária ou caprichosamente. Como notou Pedersen ${ }^{11}$, Ele está ligado aos homens, Suas criaturas, por uma aliança. Trata-se quase de uma relação contratual, em que Deus fica obrigado a agir de modo justo e misericordioso, enquanto o homem fica livre para escolher entre o bem e o mal. Há ainda um código reconhecido de conduta virtuosa, e o homem que o tiver seguido tem direito ao bem-estar, a uma consciência tranqüila, à felicidade e mesmo à prosperidade material como dons do Senhor Supremo do universo. É por isso que Jó rejeita os consolos de seus amigos: não está disposto a admitir que suas aflições derivem de pecados que haja cometido, mesmo que inadvertidamente. Ele se sente mesmo no direito de fazer exigências a Deus - "explica-me o que tens contra mim"12 -, desdenhando aqueles que, buscando confortá-lo, aconselham-no a admitir sua culpa e recuperar sua felicidade pedindo-Lhe perdão.

Deve-se enfatizar que todas as personagens da história acreditam na justiça de Deus e, portanto, que o homem virtuoso deve prosperar, que "o júbilo dos ímpios é efêmero"13. A questão está em saber se era justificada a confiança de Jó em sua própria virtude ou se seus infortúnios são prova de um pecado não admitido. Há uma questão mais profunda ainda. Mesmo que Jó esteja justificado em negar sua suposta maldade, poderíamos por isso afirmar que a virtude, entendida em termos de conduta humana, nos dá o direito de fazer exigências a Deus? A onipotência de Deus não O coloca acima das normas humanas de boa e má conduta, não $\mathrm{O}$ exime de um conceito de justiça fundado sobre uma regra de obrigações recíprocas? Pois Deus é não apenas o criador do universo, mas a própria fonte de virtude e justiça. É este o cerne de Sua fala nos magníficos capítulos 38 a 40. O homem não se encontra no mesmo nível que Deus e, por mais virtuoso que se possa sentir, não pode medir-se com Ele, tentando anular um Seu julgamento divino ou condená-Lo a fim de justificar-se $\mathrm{s}^{14}$.

É quando percebe o alcance dessa fala divina que Jó encontra a salvação. Ele não admite qualquer culpa no sentido de uma responsabilidade por ações consideradas más pelos padrões humanos correntes. Mas admite ter-se colocado em pé de igualdade com Deus, julgando por si mesmo quais condutas eram boas ou más. Foi este seu pecado. Ele aceita, como não fazia antes, a onipotência de Deus. O Deus de Jó é uma figura paterna, majestosa, poderosa, fonte da vida das criaturas, e por isso investido de autoridade inquestionável sobre todas elas; reciprocamente, como Jó insiste em lembrar, Ele é investido de responsabilidade pelo bemestar e pela felicidade de todas elas. O que Jó deve aprender é que a autoridade de Deus é suprema e inexplicável: ela não é limitada por contratos ou sujeita a qualquer coerção derivada de normas de virtude. Os sofrimentos de Jó são como severas medidas de disciplina que um pai poderia usar para corrigir um filho que, exemplar em sua conduta, começasse a perder a consciência de seu lugar e se arrogasse um status semelhante ao de seu pai; e a salvação de Jó poderia ser comparada ao momento em 
que o filho percebe e aceita sua dependência filial. Isso implica aceitar sem ressentimentos a autoridade paterna e tomá-la em princípio por benevolente, mesmo quando usada punitivamente. Esta é a essência da devoção filial, que Jó estivera a ponto de afrontar.

\section{A noção de Destino na África OCidental}

A noção de Destino ou Fado, enquanto determinante inato (ainda que não necessariamente impessoal) da história de vida de cada indivíduo, e a noção complementar de Justiça, enquanto obra de uma força personificada e deificada que reage à conduta moral de cada indivíduo e às suas relações morais com os poderes sobrenaturais, podem bem ocorrer - e de fato ocorrem - em um mesmo sistema religioso. Sob formas diversas, ambas parecem estar presentes nas religiões teísticas do Ocidente e do Oriente ${ }^{15}$. É por isso mesmo ainda mais interessante e instrutivo encontrá-las nos sistemas religiosos não-escriturais de muitos povos da África Ocidental. De fato, uma das marcas características dessas religiões, se comparadas a outras religiões africanas (por exemplo, as religiões Bantu da África Oriental e Meridional) onde o culto dos ancestrais também tem certa importância, é a ocorrência da noção de Destino. Pretendo investigar, com a ajuda de nossos paradigmas, como essas duas idéias se relacionam num sistema religioso da África Ocidental que conheço em primeira mão.

Permitam-me antes tomar alguns exemplos descritivos de outras regiões da África Ocidental. Os Yoruba da Nigéria, segundo o Dr. Bascom ${ }^{16}$, associam a sorte de uma pessoa a seu "destino". A sorte é ligada à cabeça e deriva do "criador" ou espírito guardião de cada indivíduo. Pode acontecer que alguém trabalhe duro e ainda assim continue pobre; isso se deve à má sorte que lhe coube. Enquanto isso, um outro homem, pouco trabalhador, enriquece porque sua sorte é boa. A má sorte afeta não apenas seu portador, mas também aqueles com quem ele se associa. Quanto ao Destino, é melhor citar as palavras do próprio Dr. Bascom:

“A 'sorte' de uma pessoa e o sucesso em suas atividades (econômicas ou não) depende também do Destino (ayanmope, ayanmo) ou Fado (iwa), também conhecido como 'ajoelhar-se e escolher' (akunleyan). Antes do nascimento de uma criança, dizse que sua alma se ajoelha frente à divindade (Olodumare) e escolhe (yan) seu Destino na Terra. Aquelas que fazem pedidos razoáveis de comida, dinheiro ou filhos recebem ao longo de sua existência na Terra tudo o que pediram. Entretanto, aquelas que fazem pedidos como se tivessem razão para esperar receber todas as coisas que desejam não as receberão. [...] Uma pessoa cujo destino terreno é a pobreza pode chegar a ganhar algum dinheiro se trabalhar duro, mas jamais acumulará muito. Adivinhos de várias espécies [...] são consultados para que se descubra o que o futuro reserva para cada um e o que pode ser feito para evitar os males ou assegurar um final favorável [...] entretanto, ainda que possam possam recomendar sacrifícios (ebo) capazes de influenciar eventos no futuro imediato, os adivinhos não são capazes de alterar o curso da vida ou alterar o Destino dos indivíduos." 
Crenças semelhantes são mantidas por povos aparentados do Benin ${ }^{17}$. Antes de nascer, cada pessoa conta ao Criador o que planeja fazer com sua vida e pede-lhe os meios para sua realização. Se fracassa nesta vida, diz-se que está "lutando contra o destino que traçou para si mesmo". A sorte é associada com a cabeça, de modo que se diz que uma pessoa tem uma "cabeça boa" ou uma "cabeça má" conforme tenha tido ou não sucesso em sua vida, e cada um deve fazer oferendas à própria cabeça sempre que a fortuna lhe sorrir.

Tais noções formam também o núcleo da cosmologia e do sistema religioso ricos e complexos do Daomé, descritos pelo professor Herskovits ${ }^{18}$. A religião do Daomé abrange três grandes categorias de crenças, mitologia e cultos conexos: o culto dos antepassados, o culto das grandes divindades públicas e o culto de deuses e forças pessoais. As categorias são interligadas por um "sistema de adivinhação complexo e altamente especializado", ao qual se recorre com frequiência na busca de informações sobre o destino e para aconselhamento ritual. Esse sistema de adivinhação está sob a égide do culto de Fa - "o Destino do universo tal como os deuses o desejam", na interpretação do professor Herskovits. Mas Fa é também um Destino pessoal, cujo culto é restrito aos homens, como seria de se esperar em uma sociedade com um sistema de descendência patrilinear tão altamente desenvolvido. O ponto significativo é que um homem não adquire seu Destino pleno antes de atingir a maturidade. Quando garoto, ele recebe do pai, após prévia consulta a um adivinho, um Destino parcial, simbolizado por alguns palmitos, que formam o núcleo de um pequeno santuário, e por certos tipos específicos de alimento, vestuário e proibições determinadas pelo adivinho. Um homem é levado a adquirir seu Destino pleno por uma série de infortúnios, como doença, morte dos filhos ou esterilidade de uma esposa. As mulheres têm apenas um Fa parcial, uma vez que se acredita que partilham o Destino de seus pais ou esposos, de quem são tão dependentes quanto as crianças.

"Aquilo que aguarda um homem", escreve o professor Herskovits 19 , "é pré-estabelecido". Mas há uma escapatória por meio do "trapaceiro divino", Legba, a "personificação do Acaso". Legba é o mensageiro e porta-voz dos deuses e, se corretamente propiciado, pode afastar infortúnios pré-estabelecidos. "Neste mundo governado pelo Destino", explica o professor Herkovits, "o homem pode viver seguro na convicção de que entre o Destino inexorável estabelecido para cada indivíduo e a consumação desse Destino há lugar para alguma escapatória (...)”. Há também uma outra "escapatória" por meio da doutrina das quatro almas. Um homem que atinge a maturidade chega ao sucesso por meio de suas esposas e seus filhos, seus escravos e toda a sua casa (household). Seu Destino inclui o deles, e esse Destino coletivo é vigiado por sua quarta alma, concebida como uma espécie de réplica celestial que guarda uma série de recipientes com coisas boas - como riqueza e filhos - ou más - como pobreza, doença e morte. A instalação do Destino pleno de um homem num 
objeto de culto é uma cerimônia para persuadir sua alma a selecionar as boas coisas da vida para o indivíduo.

Para rematar o conjunto, há ainda a noção de $\mathrm{Da}$, ou sorte, simbolizada para cada indivíduo pelo cordão umbilical e, em termos cosmológicos, pela cobra e pelo arco-íris. Da é responsável pelas oscilações do acaso, que se revelam nos pequenos incidentes envolvendo sorte e azar; persegue apenas homens que detêm poder e autoridade, como os chefes de casas, aldeias e reinos, a quem se manifesta através de infortúnios que lhes advêm justamente quando as coisas parecem ir especialmente bem. Daí a apreensão com que é visto: se deixado de lado, ele se mostra ressentido e perigoso. Um homem deve descobrir, por intermédio de sonhos ou de um adivinho, o que seu Da deseja que faça. Se for sábio, alojará o Da em sua casa e o cultuará. Isso fortalecerá sua sorte e o protegerá de ataques do Da de outros homens.

Por mais sumário que seja este resumo das crenças sobre o Destino no Daomé, já se pode perceber que elas dão ensejo a uma comparação com as crenças dos gregos. Também no Daomé existe um elaborado panteão de deuses celestes e terrenos, liderados por uma divindade criadora que é tanto macho quanto fêmea, além de um complexo culto dos antepassados ligado às linhagens de descendência, às comunidades locais e às unidades políticas. Os ancestrais de cada linhagem recebem um santuário coletivo e são cultuados num cômodo reservado a esta finalidade. Como nota o professor Herskovits ${ }^{20}$, o foco recai sobre a organização das linhagens de descendência. Apela-se a eles por meio de sacrifícios e preces a fim de que zelem pela saúde e pela segurança de qualquer membro do grupo que venha a se encontrar em apuros, e grandes celebrações cerimoniais são organizadas para honrá-los em ocasiões determinadas - por exemplo, a colheita. Portanto, em linhas bastante gerais, podemos dizer que os poderes sobrenaturais são invocados para proteger a continuidade e o bem-estar da linhagem, enquanto que o Destino está envolvido na trama de acasos da vida individual.

Os Yoruba, os Bini e os povos do Daomé possuem culturas estreitamente relacionadas. Todos têm, ao lado da noção de Destino, um sistema complexo de culto dos ancestrais e dos deuses (ou seres deificados). Estendi-me sobre suas crenças por serem características da África Ocidental e por termos dados etnográficos tão bons. Padrões semelhantes de culto e de crença ocorrem entre outros povos da área, incluindo alguns que não parecem ter quaisquer laços lingüísticos ou culturais com os Yoruba. Os Tallensi, sobre cujas instituições sociais e religiosas fiz um estudo de campo, são um bom exemplo desse núcleo não-Yoruba ${ }^{21}$. Volto-me para eles com um objetivo específico em mente. As descrições etnográficas generalizadas sofrem de um defeito sério: não permitem perceber como o ritual e a crença são efetivamente utilizados por homens e mulheres para regular suas vidas. Um amigo Tale certa vez comentou, enquanto voltava para casa depois do funeral de um membro de seu clã: "Agora que executamos o ritual adequado, o pesar está acalmado". 
Um outro declarou-me que, quando se consulta um adivinho, tem-se o alívio imediato de saber qual força sobrenatural está causando dificuldades e quais são as medidas rituais a serem tomadas. Nas palavras de Malinowski ${ }^{22}$, é por meio de sua compreensão "tanto como modo de ação quanto como sistema de crença, enquanto fenômeno sociológico bem como experiência pessoal" que poderemos tornar claro o sentido vivo do ritual e das crenças. Para tanto, devemos procurar entender idéias e ritos religiosos no contexto de situações, no contexto de relações sociais: e esses contextos, nós só os captamos a partir de observações de campo feitas em primeira mão.

\section{Os TAlleNSI: PARENTESCO E CULTO DOS ANCESTRAIS}

As instituições religiosas dos Tallensi não podem ser entendidas sem referência a sua organização social. Já a descrevi em detalhe noutra ocasião ${ }^{23}, \mathrm{e}$ por agora devemos nos contentar com um pequeno sumário. Comecemos com a família doméstica vivendo em sua própria parcela de terra (homestead): ela consiste de um grupo de homens, geralmente de um homem com seus filhos e os filhos destes, ao lado das irmãs solteiras e das esposas dos homens adultos; em suma, uma típica família estendida patrilincar. Os homens dessa família formam um ramo menor de uma linhagem patrilinear mais ampla, cuja ascendência comum por vezes alcança dez ou doze gerações. Como a linhagem é exógama, as filhas devem casar fora da linhagem, enquanto que as esposas vêm de linhagens adjacentes. A linhagem é um grupo de residência fixa, com certo grau de autonomia política. Mas, tal como no grupo de descendência no Daomé, o foco essencial de unidade e identidade é o culto dos ancestrais da linhagem. Assim como há uma hierarquia de abrangência crescente entre os segmentos da linhagem, do mesmo modo existe uma hierarquia de ancestrais e de seus santuários. Os membros de um segmento menor cultuam os ancestrais fundadores de seu segmento, unem-se aos membros do segmento imediatamente superior para cultuar seus ancestrais comuns, e assim por diante até que se atinja a unidade maior - a linhagem como um todo. Esse culto dos ancestrais é por definição um culto de ancestrais masculinos e patrilineares. Mas a ancestral de uma linhagem ou de um segmento é quase tão importante quanto o ancestral fundador, e o papel que os espíritos de ancestrais maternos ou de ancestrais femininas desempenham na vida de uma pessoa é tão grande quanto o dos espíritos de ancestrais paternos.

Neste sistema social, a autoridade judicial e ritual está investida nos homens que detêm o status de pais. Até a morte de seus pais, os homens não têm independência judicial nem podem executar diretamente um sacrifício para um ancestral de sua linhagem; estão, por assim dizer, incorporados ao status de seus pais. Ora, por mais consciencioso e benevolente que seja seu uso - como é o caso entre os Tallensi -, a autoridade 
paterna inevitavelmente dá origem à hostilidade e oposição reprimidas entre os filhos. Isso é reconhecido de modo inteiramente explícito e tratado por meio de várias proibições rituais entre um homem e seu primogênito. E o sentimento de oposição latente é tão forte que as proibições rituais também valem para uma mulher e sua filha mais velha.

Os pais Tale são normalmente gentis e tolerantes, especialmente com os filhos mais jovens, ainda num estágio de completa dependência frente aos genitores. Mas quando os filhos crescem, começam a cultivar a terra por si sós e a procurar esposas, o desejo de independência aparece. Tornam-se incômodos os direitos paternos - de dispor do trabalho e das propriedades dos filhos, de ser seus responsáveis frente à lei, de sacrificar em seu nome aos ancestrais, de regular suas vidas e seu comportamento moral. Surge a imagem do pai como capataz e pequeno tirano. Os Tallensi dizem que os poderes dos pais são absolutos simplesmente por serem eles os genitores de seus filhos. Se exercerão sua autoridade arbitrária ou benignamente é algo que depende de seu sentido de dever, já que não há meios pelos quais um filho possa obrigar seu pai a fazer o que quer que seja. Um pai que deseje o respeito de sua família, de seus parentes e de seus vizinhos deve sempre recompensar de modo justo os serviços e a obediência de seu filho.

Os direitos das mães são tão absolutos quanto os dos pais, mas como não têm autoridade judicial, econômica ou ritual, seus direitos tomam a forma de prerrogativas morais frente aos filhos, e não de poderes judiciais sobre eles. A mãe é concebida como nutriz amorosa, pronta a se sacrificar pelos filhos, a protegê-los e reconfortá-los. Isso não significa que as mães nunca os repreendam. Ao contrário, são elas, e não os pais, quem primeiro lhes ensinam as noções de asseio, de boas maneiras e de moralidade básica. Mas fazem uso da persuasão onde os pais dariam ordens, e contentam-se com ralhar quando os pais são por vezes levados a castigar.

Daí a diferença entre os sentimentos costumeiros quanto a pais e mães. Mas há um dever que recai sobre filhos e filhas frente aos dois genitores: o dever de devoção filial, que os obriga a honrar e respeitar os dois, a dar precedência a seus desejos, a sustentá-los é acalentá-los em sua velhice - qualquer que seja o tratamento que tenham recebido deles. $\mathrm{O}$ ato supremo de devoção filial é a realização das cerimônias mortuárias e funerais de seus pais. Para os Tallensi, trata-se aqui de uma compulsão da consciência, mas há também poderosas sanções religiosas em jogo. Deixar de realizá-las significa incorrer na ira eterna dos antepassados, pois os ritos mortuários e funerais são o primeiro passo na transformação dos pais em espíritos ancestrais, e o culto dos ancestrais é em essência a ritualização da devoção filial.

As relações de descendência e parentesco servem de ponto de referência para a organização de quase toda a vida social Tale. Um conhecimento genealógico preciso é necessário a fim de definir o lugar de cada pessoa na sociedade, bem 
como seus direitos, deveres, faculdades e privilégios. Esta é uma razão por que o culto dos ancestrais é tão elaborado. Entretanto, trata-se aqui de muito mais que um método mnemônico para regular suas relações sociais. O culto é a contraparte religiosa de sua ordem social, cingindo-a, investindo-a de um valor que transcende interesses mundanos e dotando os Tallensi de categorias de pensamento e crença com que dirigir e interpretar suas vidas e atos. Isso é perfeitamente explícito: cada atividade importante e cada relação social significante é expressa e sancionada por meio do culto dos ancestrais. E o eixo central desse culto é a relação-chave na estrutura social Tale, ou seja, a relação entre pai e filho. Somente os homens podem oferecer sacrifícios aos ancestrais, e um homem não obtém acesso a seus antepassados senão através de scu pai e sua mãe. Enquanto viver seu pai, um homem não tem direitos econômicos (à terra, por exemplo) ou status jurídico (para decidir quanto a seu matrimônio, por exemplo), a não ser através de seu pai; segue-se daí que ele não pode oficiar sozinho em ritos religiosos. À morte do pai, o filho o sucede em seu lugar na sociedade enquanto pessoa independente nos planos econômico e judicial e se torna também ritualmente adulto, apto a sacrificar e orar a seus ancestrais patrilineares por intermédio de seu pai, agora alojado entre eles. Como os ancestrais maternos desempenham um papel igualmente importante na religião Tale, as mesmas regras valem quanto à mãe. Assim, nos termos mais gerais, o culto dos ancestrais é uma transposição para o plano religioso das relações entre pais e filhos, e é a isto que me refiro como ritualização da devoção filial.

A devoção filial é na verdade uma espécie de mecanismo regulador das relações entre pais e filhos. Os costumes estabelecem que os filhos venham futuramente a suplantar seus pais, mas também os submete ao poder absoluto deles. A hostilidade que isso poderia gerar é purgada através das proibições rituais que recaem sobre o primogênito (representando seus outros irmãos): ele não pode comer com seu pai, vestir suas roupas, usar seu arco ou entrar em seu celeiro. Ele quebra esses tabus durante as últimas cerimônias funerária de seu pai. O pai deve exercer sua autoridade com benevolência; se não o faz, seus filhos serão tentados a se revoltarem e a abandonarem-no. Mas a devoção filial obriga-os a aceitar a autoridade paterna não importa como seja exercida, é eles raramente chegam à revolta de fato. Quando isto acontece, em geral por razões de ordem econômica, eles normalmente voltam ao lar depois da morte do pai, submetendo-se aos poderes místicos que ele agora detém enquanto espírito ancestral.

A descendência e o parentesco fixam o lugar de cada pessoa na sociedade, bem como os direitos, deveres e faculdades daí decorrentes, em termos de sua inclusão em grupos - como a linhagem e a família - e de suas relações com outros parentes através de seus pais, esposas e filhos. Mas há ainda um outro pólo da existência: há a individualidade de cada um. É bem verdade que, numa sociedade tão homogênea, todas as biografias são muito semelhantes, resguardadas as diferenças de sexo e idade. Mas cada biografia é também singular: alguns homens atingem os fins supremos 
da vida - saúde, longevidade e sobretudo filhos que perpetuem sua descendência e cuidem deles após a morte; não é assim com outros. Ainda que as fibras sejam comuns a todos, cada vida é um entrelaçado peculiar de bens e males. Só o culto dos ancestrais pode dar sentido a este fato.

As crenças e as práticas do culto dos ancestrais dos Tallensi encaixamse perfeitamente em sua estrutura social. Devemos notar, em primeiro lugar, que os Tallensi confrontam-se com seus ancestrais de modo muito material, já que cada parcela de terra está repleta de santuários dedicados aos espíritos ancestrais. Esses santuários, construídos com barro seco e cobertos com vários tipos de relíquias e instrumentos rituais, são de aparência bastante diversa, já que cada um simboliza uma categoria ou configuração específica de espíritos ancestrais. Os Tallensi esclarecem que esses santuários e objetos não são habitados por seus ancestrais, mas os representam e servem como altar onde os homens podem entrar em contato com eles. Em suas orações, os Tallensi chamam um grupo específico de ancestrais - sempre por seus nomes próprios - a vir ao santuário e aceitar os sacrifícios.

Os Tallensi entram em contato com seus ancestrais por meio de sacrifícios, libações e orações, mas só realizam tais ações rituais após terem consultado um adivinho. O adivinho revela-lhes qual configuração de ancestrais está envolvida na situação em causa, e quais sacrifícios eles exigem. Os adivinhos são consultados por ou em nome de indivíduos e famílias em situações extremas como nascimento, doença ou morte, em crises públicas como a seca, em momentos cruciais dos rituais ou das estações - na semeadura e na colheita, por exemplo -, antes de empresas arriscadas como a saída para a caça, ou sempre que um adulto responsável sente-se inclinado a tanto. Desse modo, o culto dos ancestrais é permanentemente envolvido nas atividades dos vivos; mas é típico que os ancestrais manifestem seus poderes e seus interesses em ocorrências imprevisíveis, que transtornam as expectativas e rotinas normais; assim agindo, eles apresentam suas exigências e propiciam a submissão. Essas ocorrências são por vezes tomadas como favoráveis aos descendentes, ainda que geralmente sejam vistas como infortúnios. Além disso, os ancestrais manifestam-se de modo diferente para homens e para mulheres e com diferentes resultados ao longo dos estágios sucessivos da vida individual.

\section{Ciclo de vida e Destino edípico}

Sempre que examinamos a vida de qualquer pessoa, o ponto de partida essencial é o simples fato de ela ter nascido e sobrevivido. A este fato os Tallensi fazem corresponder o conceito de espírito guardião (seyr) em seu culto dos ancestrais. Pouco depois do nascimento de uma criança, seu pai determina, com a ajuda de um adivinho, qual de seus ancestrais, associado a qual configuração de poderes ancestrais, deseja servir de tutor da criança; e o que esse espírito guardião faz consiste tão-somente em supervisionar e preservar a vida, a sobrevivência de seu protegido. 
O caso de Dentiya ilustra bem este ponto. Certo dia ele apareceu com uma ovelha para ser sacrificada a seu espírito guardião. Nos últimos anos, sua primeira esposa havia morrido, a segunda perdera um bebê e agora a terceira estava grávida. Um adivinho revelara-lhe que tudo isto fora obra de seu espírito guardião. O espírito guardião dissera que havia preservado a vida de Dentiya ao longo de várias provações, mas que Dentiya o havia negligenciado; por isso causara a morte de sua esposa e de seu filho. Agora que sua terceira mulher estava grávida, o espírito guardião exigia, em primeiro lugar, reparação, e, em segundo lugar, a custódia da criança por nascer. A ovelha era uma oferenda de reparação, anuência e conciliação, feita com orações pelo parto seguro do bebê, pelo bem-estar da mãe e pela saúde do pai e dos parentes. No caso, Dentiya era o protegido de ancestrais de sua linhagem patrilinear agrupados na configuração da linhagem suprema boyar $^{24}$, e a oferenda seria feita em seu santuário pelo líder do segmento de linhagem de Dentiya. Mas todas as espécies de ancestrais tomam crianças como protegidos seus. Além disso, sempre se fazem oferendas ao espírito guardião nos estágios decisivos do ciclo de vida. Por exemplo, um marido leva a seu sogro uma galinha ou uma galinha-d'angola para ser oferecida ao espírito guardião de sua esposa quando esta se encontra nas últimas fases da gravidez; e, mais importante que tudo, o espírito guardião de uma pessoa deve ser informado imediatamente da morte desta, tão logo a vida do protegido tenha se extinguido.

Mas a vida - simbolizada para os Tallensi pela respiração (ovor) - é apenas a matéria-prima da existência. O que cada um fará dela depende de outras forças espirituais. Tomemos um caso extremo mas razoavelmente comum. O filho de seis anos de um amigo próximo sofria de uma doença longa e debilitante; remédios haviam sido testados em vão, e os adivinhos atribuíam a doença à raiva de ancestrais, a quem então prometeram oferendas caso a criança se recuperasse. Mas a criança morreu. Durante a sessão de adivinhação que acompanha a cerimônia mortuária, constatou-se que a causa da morte havia sido o Destino Pré-natal (NuorYin) da mãe da criança. A identidade social de uma criança de seis anos está de tal forma fundida à de seus pais, e mais particularmente à de sua mãe, que tudo o que acontece à criança é atribuído às relações da mãe com as forças espirituais. Por essa mesma época, um jovem de dezoito anos morrera de uma doença consumptiva similar, e revelou-se que a morte era devida ao Nuor-Yin do próprio rapaz, já maduro o bastante para ter sua própria identidade social. Mas quando seu irmão, de vinte e cinco anos e recém-casado, morreu de disenteria aguda, os adivinhos atribuíram a morte à configuração de ancestrais da linhagem reunida no santuário máximo da linhagem. Essas diferenças na atribuição da causa mística da morte, tão obviamente correspondentes às posições dos indivíduos na estrutura social, também se refletem no pesar dos atingidos e no círculo de parentes e membros do clã envolvidos. Quando uma criança pequena morre, os ritos funerários são concluídos rapidamente, e só os parentes mais próximos comparecem; mas quando um ancião da linhagem 
morre, os ritos funerários são elaborados e prolongados, e nele tomam parte todos os clãs vizinhos, bem como um enorme círculo de parentes e membros do clã.

Mas o significado pleno do Destino Pré-natal torna-se mais claro a partir do modo como afeta as mulheres. Na visão Tale, ninguém é tão desafortunado ou tão infeliz como uma mulher sem filhos. Se, como ocorre freqüentemente, uma jovem esposa perde seus filhos um atrás do outro por aborto natural ou na primeira infância, seu desconsolo e desânimo tornam-se crônicos - e o mesmo ocorre com o marido. Suspeita-se então do Destino Pré-natal dela - coisa que os adivinhos logo confirmam. Mas, enquanto há vida, há esperança, e, como em outras partes da África Ocidental, há uma saída tradicional para o problema. Há um procedimento ritual para exorcizar o Destino Pré-natal em casos dessa espécie. Os ritos são executados pela linhagem do pai da mulher, mas em seu domicílio de casada, e a lógica subjacente ao procedimento é expressa em termos claros. Em primeiro lugar, um sacrifício é oferecido aos ancestrais da linhagem da mulher, que são chamados a expulsar o mau Destino Pré-natal. Pois não fora por intermédio de sua beneficência que ela nascera naquela linhagem, e ainda por cima mulher? Eles devem cuidar para que sua feminilidade seja consumada. Ela se casara corretamente, seu contradote (bride-price) fora aceito e seu esposo tinha direito a ter filhos dela. Para que mais serve o matrimônio? A descendência de uma mulher tem íntimas relações de afeição, dever e privilégio com os parentes paternos de sua mãe e deles recebe serviços rituais essenciais. Os parentes paternos da mãe recebem gado de seu contra-dote em sacrifício; mais importante ainda, recebem serviços rituais da descendência dela. Assim, sua fertilidade beneficia-os em proporção direta, tanto material quanto espiritualmente. Por justiça para com todos, deve-se permitir que ela tenha filhos. A isto se segue uma cerimônia mágica onde a mulher é purgada por um banho que simbolicamente remove e expulsa o Destino Pré-natal.

É fácil de perceber que o Destino Pré-natal de uma mulher está ligado a seu status em sua própria linhagem. Pois foi seu nascimento como mulher em sua linhagem particular que a dotou de fertilidade, e foi o fato de seus pais a terem criado até a maturidade que a capacitou a pôr sua capacidade procriativa a serviço da linhagem de seu marido. Quando, mais raramente, um homem é vítima de seu Destino Pré-natal, o sintoma geralmente é seu insucesso, em geral devido a alguma doença, em se casar ou em ganhar a vida sozinho. Nesse caso, membros de sua própria linhagem, assistidos por membros da linhagem de sua mãe, executam o exorcismo. Enquanto membro de sua linhagem, seus dotes naturais devem derivar de seu nascimento e de sua educação; se esses dotes lhe faltam, somente seus ancestrais, ao lado dos de sua mãe, podem salvá-lo.

O que é então o Destino Pré-natal? Os Tallensi tem uma doutrina muito clara. A fonte última de tudo o que há na Terra é o Céu (Naawun). Mas não há mitos narrando a criação ou, como dizem eles, o jorramento ( $b a h$ ) do mundo, e nenhum santuário para cultuar o Céu, que é simplesmente a causa final de tudo o que existe. 
Antes de seu nascimento, toda criança está "com o Céu", não em sentido literal, mas no sentido simbólico de estar em criação. Nessa ocasião, a criança declara seus desejos para o Céu - daí o termo Nuor-Yin, literalmente Destino Falado. A criança pode declarar que não quer ter pais, esposa, filhos, terra ou gado. Isso significa que ela rejeita uma existência humana comum, ainda que não possa evitar seu próprio nascimento. É esse seu Destino Pré-natal, por vezes tão poderoso que seu portador morre ou causa doença ou mesmo morte a seus pais, cônjuge ou filho.

Noções muito semelhantes ocorrem em outras partes da África Ocidental, como já pudemos ver; mas colocá-las em seu contexto ou situação social lança uma luz significativa sobre elas. Por um lado, elas explicam e reasituam nos costumes as doenças e insucessos que desafiam o conhecimento e as habilidades do povo. Portanto, é óbvio para o observador que o ritual de exorcismo traz conforto e esperança aos que sofrem, bem como a seus parentes. Mas as doenças mais sérias não podem ser tratadas por meio das técnicas mágicas e religiosas que formam a base de todas curas Tale. Um elemento suplementar intervém: as vítimas do Destino Pré-natal formam um grupo à parte. Elas estão, ao menos potencialmente, num limbo da estrutura social, jovens demais para se envolverem em tarefas e relações sociais de maior responsabilidade ou então portadoras de deficiências físicas ou psicológicas que os põem em risco de não terem filhos e, em consequiência, de serem esquecidos socialmente. Ao que parece, a noção de Destino Pré-natal serve como álibi legítimo, ao livrar os paranpes e a sociedade em geral de responsabilidade ou culpa pelos problemas do indivíduo; na verdade, a noção exonera-o a seus próprios olhos, já que ele não tem como saber que é vítima de seu Destino Pré-natal antes que um adivinho o revele.

\section{Bom Destino, os ESPíRITOS ANCESTRAIS E OS PAIS}

A noção de Destino Pré-natal entre os Tallensi é, muito claramente, uma versão mais simples do Destino edípico. Há entretanto um outro aspecto do Destino, no qual prevalece a benevolência. Ele não se torna ativo antes da adolescência, e diz respeito exclusivamente aos homens, de modo que todo homem casado tem seu santuário do Bom Destino (Yin). Enquanto for jovem e dependente do pai, seu santuário fica nos aposentos de sua mãe. Quando tem seus próprios filhos, o santuário é transferido para os aposentos de sua esposa. E por fim, quando ele herda a posição social de seu pai, o santuário é trazido ao ar livre para deixar claro quem está agora controlando e protegendo todo o grupo familiar. Assim, o santuário funciona como registro ritual da vida do indivíduo, da infância ao umbral do status jurídico de adulto, acompanhando seu envolvimento crescente em relações sociais de responsabilidade: casamento, paternidade, independência econômica, chefia da família e finalmente o status de ancião da linhagem. As mulheres não são dotadas individualmente de um Destino dessa espécie, uma vez que não possuem autonomia jurídica ou religiosa. Na con- 
dição de filhas e irmãs em sua família paterna, estão sob a autoridade e a responsabilidade de seus pais. Enquanto esposas e mães em suas famílias conjugais, submetemse ao poder de seus esposos. Entende-se que o ciclo de vida de uma mulher é determinado primeiramente pelo Destino de seu pai e, posteriormente, pelo de seu esposo.

O Bom Destino de um homem deriva em última instância de seus desejos pré-natais desconhecidos; quando age, fala-se do Céu que intervém em sua vida e em suas realizações. Mas esse Destino se manifesta por meio do que nós chamaríamos de acasos e coincidências; o repertório destes é completamente estereotipado, apenas a combinação de elementos é específica para cada indivíduo. Como os Tallensi dizem, todo mundo fica doente às vezes, casa-se, tem filhos, mata animais nas caçadas, e assim por diante. Por que então a doença deve acometer uma determinada pessoa em determinado momento? Por que certo homem deve ser feliz em seus casamentos e ter muitos filhos, enquanto seu irmão fracassa em suas tentativas? Não se pode prever o curso da vida, pois esta é governada por forças além do conhecimento e do controle humanos - forças que os Tallensi conceitualizam nos termos de seu culto dos ancestrais. Assim, a história de vida de cada indivíduo é singular, ainda que os eventos que a constituem sejam semelhantes aos de tantas outras vidas; e seu curso total depende de seu Destino individual. É por isso que uma oferenda a um santuário Yin é freqüentemente consumida apenas pelo dono, ao lado de sua mulher e seus filhos, não se permitindo a participação de seus parentes consangüíneos, ao contrário do que acontece em outros sacrifícios.

Tomemos alguns exemplos. Quando tinha por volta de dezesseis anos, $\mathrm{Za}$ saiu certo dia a pastorear o gado de seu pai. Chegando a uma lagoa, viu um crocodilo na margem e imediatamente o matou; o animal foi trazido para casa e comido pelos mais velhos. Como era seu dever, o pai de Za foi consultar um adivinho a respeito do incidente. $O$ adivinho lhe disse que se tratara de uma manifestação do Destino de Za: eram sua mãe e seu avó paterno que se manifestavam através da flecha utilizada e do crocodilo morto. Eles eram o Destino de Za, que deveria erigir um santuário e fazer sacrifícios para eles, que então zelariam por seu bem-estar. Construiu-se então um pequeno santuário com barro, onde foram inseridos a flecha e o crânio do animal, como símbolos dos ancestiais que haviam escolhido Za.

Esta é uma história típica sobre a origem do santuário do Destino de um homem. Uma outra, ilustrando um aspecto diferente da noção, é a de Kunyaaba. Logo quando começou a cultivar a terra como homem maduro, por volta dos dezoito anos, uma doença nos pés o deixou prostado. Seu pai foi a um adivinho, e constatousc quc o avô c o bisavô paternos do rapaz estavam se manifestando como seu Destino. A doença era sinal de que eles exigiam serem aceitos como Destino do rapaz, cuja enxada era símbolo material de seu interesse e disposição. Além disso, desejavam que ele jamais comesse do grão que ele próprio tivesse plantado. Este é um tabu pessoal bastante inconveniente numa economia doméstica como a dos Tallensi, e de início Kunyaaba não gostou muito da idéia. Ele se curou e voltou a cultivar, mas 
logo adoeceu de novo e mais seriamente. Desta vez o adivinho revelou que os ancestrais que haviam assumido seu Destino estavam irritados com sua ousadia e agora exigiam que ele abandonasse inteiramente a lavoura. Foi um grande golpe, já que não há outras atividades igualmente gratificantes para um jovem vigoroso e capaz. Mas não havia escolha, pois a desobediência implicaria risco de doença ou mesmo de morte para ele, sua mulher ou seus filhos. O tabu foi uma das razões para Kunyaaba ir trabalhar em outra parte. Relutava em falar do assunto, como se sentisse vergonha, e sublinhava o caráter irremediável de sua situação.

Esse tipo de tabu pessoal é freqüentemente imposto pelos ancestraispatronos, que podem proibir seus protegidos de vestir adornos de tecido, comer certos pratos, cortar o cabelo, executar certas espécies de trabalho e assim por diante. Esses tabus são observados à risca, já que o preço da desobediência pode ser um infortúnio, uma doença ou mesmo a morte de uma esposa ou filho. É significativo que esses ancestrais-patronos raramente causem a morte de seu protegido; essa sanção extrema é geralmente usada contra seus dependentes (como Deus fez a Jó) a fim de dobrar o indivíduo. O Destino é em si mesmo benevolente, contanto que o protegido aceite seus ancestrais-patronos, rendendo-lhes serviços e obediência, isto é, observando os tabus que lhe impõem, por arbitrários e inconvenientes que sejam do ponto de vista racional da vida cotidiana Tale.

Ainda outro aspecto do Destino aparece no caso de Luoni. Certa vez, num rio distante, ele matou um crocodilo macho adulto, que provou ser veículo de seus ancestrais-patronos. Desde então, ele é periodicamente despertado por um pesadelo em que se vê perseguido por um crocodilo. Ele se levanta, pega um chocalho e, em plena escuridão, corre para o rio e de lá para a casa de seu tio materno, de onde provêm seus ancestrais-patronos - e assim amaina o ataque. Sua família não se envolve, pois, como diz seu filho, "Isto é assunto dele; não temos nada a ver com isto." O Destino de um homem muitas vezes se afirma dessa maneira quando sua manifestação esteve ligada à morte de algum grande animal de caça - e continua fazendo-o até a instalação final do santuário. Esta acontece nos últimos anos de vida do indivíduo, quando sua casa, seus filhos e sua própria sobrevivência são provas tangíveis da beneficência de seu Destino. É conum que os homens mais velhos fiquem sabendo, através de adivinhos, que seu Destino exige o sacrifício de uma vaca como prova de gratidão por seus longos e contínuos serviços; esse sacrifício é sempre uma ocasião triunfal.

O Destino de um homem consiste, portanto, de uma configuração singular de ancestrais que de modo próprio decidiram vigiar seu ciclo de vida e frente aos quais o indivíduo é pessoalmente responsável. Ninguém mais, nem sequer seu irmão, tem a mesma configuração de ancestrais-patronos ${ }^{25}$. Estes últimos são sempre antepassados imediatos e geralmente da linhagem paterna. Manifestam-se pela primeira vez através de alguma experiência ou ato crítico num estágio determinado do ciclo de vida individual: uma doença, um feito produtivo, como abater pela 
primeira vez uma grande presa ou destacar-se na lavoura. As relíquias materiais desses eventos formam o santuário de seus ancestrais-patronos. Em troca da submissão e dos serviços, espera-se do Destino de um homem que lhe preserve a saúde, a vida e o bem-estar da família, que lhe traga boa sorte em suas atividades econômicas e aspirações sociais, e que, abençoando-o com filhos e netos, garanta-lhe a imortalidade de que gozam os ancestrais.

Este último item constitui a prova suprema da boa-vontade de seus ancestrais, e o poder do Destino neste domínio se revela de duas maneiras em especial. Em primeiro lugar, muito embora todas as categorias de ancestrais possam se tornar e, como já mostrei, de fato se tornam espíritos guardiães dos filhos de um homem, são os ancestrais-patronos que predominam entre eles. Desse modo, a realização maior de um homem - sua descendência - é identificada como seu Bom Destino.

Em segundo lugar, pode-se apelar ao Destino a fim de interpretar a ambivalência da relação entre pais e filhos. Os pais desejam e necessitam de filhos para perpetuar sua existência social, mas tornam-se cada vez mais relutantes em ceder seu lugar aos filhos à medida em que suas condições físicas e sociais se deterioram e as dos filhòs se fortalecem. Os filhos aceitam seus status dependente com respeito afetuoso e devoção filial; mas a cada novo passo rumo à autonomia jurídica, especialmente a partir do momento em que se casam e têm seus próprios filhos, eles se impacientam mais e mais com a autoridade paterna. Sob a solidariedade fundada em interesses comuns e dependência mútua, há oposição e rivalidade entre as gerações. Geram-se aí as tensões simbolizadas e escoadas pelos tabus que pesam sobre o primogênito. Os Tallensi os explicam por meio da noção de Destino. Eles dizem que o Destino de um pai e o Destino de seu primogênito são hostis um ao outro. Durante a infância do filho, o Destino do pai é superior. Conforme o filho se desenvolve física e socialmente, seu Destino fica mais e mais forte - na verdade, é só por ter um Destino forte que o filho consegue crescer. Isto representa uma ameaça para o Destino de seu pai. Seus dois Destinos são inimigos, um quer destruir o outro, de modo que seu protégé seja o chefe da casa, livre e desimpedido para render-lhe sacrifícios e serviços. É por isso que um primogênito casado e com filhos não pode usar a mesma entrada que seu pai, para evitar o perigo de encontrá-lo face a face, Destino contra Destino. Isso faz pensar nos efeitos fatais que um mau Destino Pré-natal traz aos pais ou filhos da vítima. Deduz-se daí que o Destino de uma pessoa (o que os gregos chamavam de daemon), na forma benigna como na maligna, se afirma em oposição ao de seus pais (ou antes ao de seu pai, já que o de sua mãe é submetido ao de seu pai).

Lembrando que um filho só chega à independência jurídica e ritual após a morte do pai, devemos concluir que esta é uma vitória do Destino do filho. É uma vitória inevitável, mas os Tallensi não admitem este fato. Se o fizessem, anulariam o efeito estabilizador dos tabus dos primogênitos e destruiriam a própria base da relação entre gerações sucessivas. Ao invés, enfatizam o dever filial supremo de reali- 
zar os ritos funerários de seus pais. Esses ritos têm por efeito transformar o pai morto (ou a mãe, segundo o mesmo princípio) em espírito ancestral e trazê-lo de volta para a família em seu novo status espiritual. Sua autoridade jurídica - mundana e material - é transmutada em poder místico - isto é, poder absoluto, autocrático e impredizível, por estar além do controle das sanções morais e jurídicas. É como se, em nome de sua própria continuidade, a sociedade recompensasse os pais pela perda de poderes materiais com poderes espirituais exorbitantes. Esta cessão de poderes reconcilia-os com os filhos que os desalojaram, ao mesmo tempo exonerando estes últimos da culpa, como se percebe no simbolismo das cerimônias funerais e nas crenças Tale sobre as causas últimas da morte, que logo examinarei.

Quais serviços são devidos aos ancestrais-patronos? Em termos formais, os mesmos que se devem a quaisquer ancestrais, qualquer que seja a configuração em que são cultuados. Em primeiro lugar, seus descendentes devem aceitá-los ${ }^{26}$ e dar-lhes um santuário. Isto é feito a uma ordem sua, transmitida por um adivinho, e conforme o padrão costumeiro, ou seja, a partir de infortúnios ou coincidências interpretados como manifestações dos ancestrais. Tendo recebido seu santuário, os ancestrais são reintroduzidos, sob forma de espíritos, nas casas e nas famílias de onde a morte os separara em sua forma física. Continuarão a afirmar seu poder através dos problemas que causam, mas os meios de aplacá-los (e de assim aquietar as ansiedades e a perturbação das expectativas rotineiras que causam) estão agora à mão. Em segundo lugar, os ancestrais-patronos devem receber oferendas e libações regulares, o que para os Tallensi significa dar-lhes comida e bebida, expressando assim reverência e atenção filiais. Eé significativo que também este serviço só seja prestado em resposta a um infortúnio de advertência ou a uma ameaça de infortúnio. Isto vale mesmo para sacrifícios em ocasiões sazonais ou cerimoniais, como a época da colheita. Cada chefe de casa sacrifica a todos os seus santuários de ancestrais, sempre de acordo com as exigências comunicadas através dos adivinhos. Em terceiro lugar, há a observância dos tabus, que simboliza a submissão aos ancestrais e a sujeição às normas e costumes instituídos por eles. É aqui que se torna aparente a faceta temível dos ancestrais, particularmente dos ancestrais-patronos e dos ancestrais-adivinhos. No caso dos ancestrais-patronos, ela se manifesta diretamente em pésadelos que só um ato de obediência quase ritual pode mitigar, e indiretamente na antecipação ansiosa de aflições sobrenaturais por culpa da desobediência. Ancestrais-patronos não são benevolentes por afeição a seus descendentes, mas por interesse próprio ancorado em seu poder. Sua solicitude não é conquistada por demonstrações de amor, mas por provas de lealdade.

O que distingue o culto do Destino do culto de quaisquer outras configurações de ancestrais está em que esta relação ritual, ao contrário de todas as outras, é fechada aos parentes consangüíneos e demais membros do clã. Os Tallensi têm uma percepção aguçada das diferenças individuais de caráter e inclinação, mas isso não os leva a considerar a individualidade como fruto de um processo interno do indivíduo. Um indivíduo é aquilo que alcançou fazer, e cada realização importante é creditada à boa-vontade de seu 
Destino. Seu Destino o ajuda trazendo-lhe boa sorte - que os Tallensi, como outros povos da África Ocidental, associam com a cabeça - ou afastando adversidades. Para o pensamento Tale, tudo o que acontece tem causas e pré-condições materiais, que entretanto só se tornam efetivas por graça de entidades místicas que são os árbitros supremos da natureza e da sociedade. Um homem que deseja prosperar deve ser habilidoso, diligente e econômico; mas isso não é suficiente, pois sem a beneficência do Destino, seus esforços não darão em nada; e nem mesmo essa beneficência basta, pois por detrás do Destino está o poder coletivo dos ancestrais, em especial dos onipotentes ancestrais da linhagem.

Nessa relação especial de um homem com seus ancestrais-patronos (como com quaisquer outros ancestrais) conta pouco a moralidade no sentido de comportamento virtuoso. Interessam apenas os serviços e a obediência. Um homem mau para os padrões Tale pode prosperar enquanto seu irmão fracassa em tudo. Mas nem mesmo o serviço assíduo constitui uma garantia: os ancestrais se ofendem fácil e inesperadamente - o que só se revelará quando alguma coisa der errado. É por isso que até mesmo cerimônias fixas são potencialmente arriscadas: pode-se constatar que um grupo de ancestrais sentiu-se ofendido com a atenção dedicada a um outro grupo. Ancestrais encolerizados podem prevalecer sobre o Destino do indivíduo e causar-lhe desastres, como o provam as consultas a adivinhos feitas após a morte do indivíduo. Em consequiência, sempre que se oferece um sacrifício a uma configuração de ancestrais, deve-se igualmente fazer oferendas a todos os outros ancestrais do oficiante. Assim, sempre que o sacrifício maior couber ao santuário do seu Destino, o homem adulto deve antes passar por todos seus outros santuários de ancestrais - o santuário do Destino de seu pai, seu próprio santuário adivinhatório (divining shrine), o santuário dedicado a sua mãe (caso já tenha morrido) e o santuário dos ancestrais da linhagem (caso o indivíduo seja suficientemente avançado na hierarquia). Cada qual recebe um pequeno sacrifício, talvez apenas uma libação de água; o oficiante conta-lhe as circunstâncias da ocasião e pede-lhe que mostre boa-vontade. Os Tallensi explicam em termos de parentesco a necessidade de tais rituais. Enquanto juridicamente irresponsável durante a vida do pai, cada homem precisa do consentimento (ou ao menos da benção) de seu pai e muitas vezes também dos anciãos da linhagem antes de fazer qualquer coisa de importante. É necessário também contar tudo à mãe, em respeito à sua posição. $\mathrm{O}$ mesmo padrão vale para transações com os ancestrais.

Vale notar que essa pluralidade de poderes ancestrais competindo entre si em suas exigências aos fiéis funciona de fato como uma espécie de salvo-conduto na vida cotidiana. Como não há um Deus único e soberano - como o de Jó -, ninguém se sente com direito a recompensas com base num código de conduta ou merecedor de punições por havê-lo deliberadamente transgredido. Cada qual vive segundo sua compreensão mundana, guiado pelas sanções morais e jurídicas da 
sociedade, sabendo que os ancestrais fazem justiça conforme seus próprios critérios e que é impossível agradar a todos simultaneamente.

Há aqui uma aparente inconsistência no pensamento Tale, pois não se considera que os ancestrais sejam inteiramente indiferentes a valores morais. Pelo contrário, eles são guardiães ciosos dos mais altos valores morais, isto é, daqueles valores axiomáticos que determinam as regras da conduta ideal. A primeira estabelece o parentesco como relação inescapável (binding) num sentido absoluto. Decorre daí a segunda regra: o parentesco implica harmonia (amity) num sentido absoluto. A terceira regra é a mais fundamental: ela postula que a relação essencial entre pais e filhos, expressa nos cuidados devotados do pai e na dependência afetuosa do filho, não pode jamais ser violada e é, ncsse sentido, sagrada. Ela é, na verdade, a fonte das outras regras. Os Tallensi acreditam que quem viola estas regras é passível da punição mística maior - a morte. Pois mesmo que cada morte tenha suas causas materiais, nenhuma morte ocorre contra a vontade dos ancestrais.

Agora podemos entender melhor a questão. Não se trata de uma questão de moralidade no sentido de conduta virtuosa. Não se trata, digamos, de lidar honestamente com os vizinhos, abster-se do adultério ou jamais cometer um assassinato. A virtude nesses domínios de ação não é suficiente para conseguir as bênçãos dos ancestrais: um malfeitor escaparia a sua ira enquanto seus crimes não infringissem a regra de harmonia entre parentes. Trata-se de uma questão de relações morais, não de boas ações. O que os ancestrais exigem e fazem valer sob pena de morte é a conformidade com os axiomas morais básicos como pré-requisitos de todas as relações sociais; e estas últimas são a contrapartida, no domínio do parentesco, das obrigações existentes entre as pessoas e seus ancestrais no domínio religioso - como seria de se esperar, já que estas obrigações derivam daquelas relações sociais por extensão e transposição para o domínio religioso.

$\mathrm{O}$ ponto que me preocupa aqui é bem ilustrado pela história de $\mathrm{Pu}$--yii. Tentado pela possibilidade de ganhar dinheiro, ele desertou seus parentes patrilineares para se aliar a uma linhagem rival. Então, no ápice da prosperidade, envolveu-se num acidente de caminhão. Por sorte escapou com vida, mas também com ferimentos graves numa perna. Ao consultar um adivinho, ficou sabendo que o acidente fora produzido por seus ancestrais de linhagem. Desertar seus parentes fora um pecado, já que ele doravante não poderia mais juntar-se a eles em harmonia a fim de sacrificar aos antepassados. Isto era o mesmo que abandoná-los, e agora eles, enraivecidos, tencionavam matá-lo. Contudo, disse o adivinho, seu Destino lhe era propício e intercedera para salvar sua vida. Ele deveria desculpar-se junto aos anciãos de sua linhagem, oferecer um carneiro a seus ancestrais de linhagem a fim de mostrar sua contrição e submissão, e fazer um sacrifício de agradecimento a seu Destino - além de pôr fim a sua associação com a linhagem rival. Pu--yii era um homem experiente, viajado e hábil nos negócios, mas consentiu prontamente com tudo, acreditando que a morte seria a punição de uma nova desobediência. 


\section{A SUPREMACIA DOS ANCESTRAIS DE LINHAGEM}

No sistema religioso dos Tallensi, a última palavra cabe aos ancestrais de linhagem. O conjunto destes é composto pelos antepassados de uma pessoa ou grupo em linha estritamente patrilinear, estendendo-se do ancestral fundador e sua mulher até um pai recentemente morto. Eles são onipotentes, mas não uniformemente benevolentes ou malévolos: são justos ${ }^{27}$, e sua justiça está voltada para a manutenção das normas e valores morais ou religiosos sobre os quais se assenta a ordem social. Eles o fazem através do poder de vida e morte que detêm. A distribuição da vida, que supera todas as outras formas do bem, e da morte, que é o fim de tudo (como dizem os Tallensi), cabe aos ancestrais pelo que poderíamos chamar de direito de paternidade primordial. Seus poderes equivalem aos poderes de um pai, incomensuravelmente ampliados e santificados, ou seja, livres dos controles da cooperação e da reciprocidade, da consciência e do amor tal como agem na vida familiar. Mas este caráter especial só lhes pertence na configuração específica de ancestrais de linhagem em seu santuário próprio - pois nada impede que os mesmos ancestrais surjam em configurações diferentes.

Como funciona então sua justiça? Tomemos o caso de uma moça solteira, perseguida por seu Destino Pré-natal. A possibilidade de livrar-se desse Destino depende da vontade de seus ancestrais de linhagem. É de seu interesse que haja filhos e netos para manter a existência da ordem social, para servi-los e reverenciálos. E isto pode pesar mais na balança da justiça ancestral do que crimes e pecados de omissão. Ou então imaginemos o caso de um homem com um Bom Destino, que teve uma vida longa e bem-sucedida. Como dizem os Tallensi, no fim o seu dia deve chegar e ele morrerá. A causa material, que qualquer um pode constatar, pode ser a idade avançada ou a doença; mas o momento e as circunstâncias exatas dependem da vontade dos ancestrais. Não importa quão virtuosos, respeitados e devotos tenham sido, sua morte é invariavelmente interpretada como conseqüência de uma falha, sua ou de seus predecessores, no cumprimento das tarefas de devoção aos ancestrais. Pode ser um pecado há muito esquecido, seu ou de seu pai, que ele e seus parentes consideravam expiado mas que agora, em retrospecto, mostra ainda ser motivo de ressentimento entre os ancestrais. Ou pode ser uma dívida ritual aparentemente corriqueira: o mais virtuoso dos homens sempre tem alguma dívida dessa espécie em pendência, e pode ser que seus filhos ou irmãos não saibam dela. Por exemplo, todos os homens maduros têm obrigações rituais derivadas de seu status na linhagem e na sociedade. Mas como os Tallensi concebem a oferenda como resposta a uma exigência formulada pelo ancestral, e não como doação espontânea, eles tendem a adiar essas obrigações. A exigência pode então vir com o sinal costumeiro de doença, infortúnio casual ou mesmo como um golpe de boa sorte. Mas pode acontecer que ela não seja revelada até que a morte leve o indivíduo em questão ou um de seus dependentes. Assim, todo homem 
maduro sabe que algum dia ele deverá completar a instalação do santuário de seus ancestrais-patronos; mas ele acaba por postergar a execução da obra, pensando que terá tempo de sobra quando for velho e tiver filhos e netos como prova da benevolência de seu Destino. A obrigação é bem conhecida; se ele morrer antes de cumpri-la, o adiamento pode vir a ser tido por causa mística da morte, e os adivinhos proclamarão que sua ingratidão havia enfurecido seus ancestrais-patronos, que estes o haviam matado com o consentimento dos ancestrais da linhagem. Para dar outro exemplo: um homem que recebe a custódia de um santuário da linhagem pode de boa-fé adiar a cerimônia de empossamento até que tenha reunido grãos suficientes para a cerveja e gado o bastante para os sacrifícios. Se ele morrer nesse meio tempo, sua demora pode ser revelada como causa mística de sua morte. Por fim, há "a vaca do contradote" que um homem deve a seus ancestrais de linhagem quando consegue casar uma de suas filhas; adiar esse sacrifício pode acabar com a morte dele próprio ou de um de seus dependentes.

Em suma, por mais consciencioso que se seja no cumprimento de suas obrigações rituais, há sempre uma escorregadela: a vontade dos ancestrais só é conhecida a posteriori, a gama de ancestrais que podem estar se manifestando a fim de reclamar seus direitos é extraordinariamente ampla, e as dívidas rituais transferem-se de geração a geração. O sistema como um todo é inabalável, já que o critério invocado é o serviço ritual, e não uma forma de conduta que pudesse ser julgada pelos próprios homens. Não importa o que seja, tudo o que os ancestrais fazem deve ser - e portanto é - aceito como justo. O paralelo com Jó é óbvio. Mas diferentemente do herói bíblico, os Tallensi não tentam contestar os direitos e a autoridade de seus ancestrais, ainda que comumente peçam-lhes benevolência e protestem seus próprios méritos.

\section{JustiÇA, RESPONSABILIDAdE E O CULTO DOS ANCESTRAIS}

As crenças e práticas religiosas Tale servem, tal como as de outros povos, a propósitos catárticos. Elas proporcionam alívio face ao pesar, à raiva e à angústia despertados pelos problemas materiais, pela cỉoença ou pela morte. Mas não é este o aspecto de seu sistema religioso que nos diz respeito. Interessa-nos antes a catarse mais profunda, tanto social quanto individual, proporcionada pela fusão das noções análogas às de Édipo e Jó em seu sistema religioso.

Estou pensando particularmente na questão de como atribuir responsabilidades pelas vicissitudes da vida. Crenças em bruxaria, magia ou feitiçaria ocupam lugar relativamente menor no pensamento Tale, em contraste com várias outras religiões africana ${ }^{28}$. A cosmologia Tale é inteiramente dominada pelo culto dos ancestrais. Mesmo suas elaboradas instituições totêmicas, o culto da Terra ${ }^{29} \mathrm{e}$ as crenças sobre as perigosas qualidades místicas de certas árvores, animais e outros fenômenos naturais são subordinadas a esse culto. Em consequiência, é inconce- 
bível para os Tallensi atribuir infortúnios graves tão-somente à ação de um feiticeiro, de um remédio ou de uma árvore ou animal misticamente "maus". A decisão final cabe aos ancestrais. Isso significa que a responsabilidade última é projetada para fora do corpo político existente, ou seja, não sobre vizinhos, parentes ou fenômenos naturais, como acontece em sociedades com crenças desenvolvidas sobre bruxaria e magia ${ }^{30}$. Mas não se anula com isso a responsabilidade humana. O que o culto dos ancestrais oferece é um esquema institucionalizado de crenças e práticas por intermédio das quais os homens podem aceitar alguma espécie de responsabilidade pelo que lhes acontece e ainda assim sentir-se livres de culpa por não conseguirem controlar as vicissitudes da vida. A responsabilidade moral pelas manifestações do Destino ou dos ancestrais recai sempre sobre a pessoa (ou seu superior jurídico) que as sofre. Ao aceitar os ancestrais que se manifestam para ela - e mais tarde ao dedicar-lhes um santuário -, ou quando admite uma falha nos serviços devidos e oferece reparação na forma de sacrifícios, a pessoa está aceitando sua própria responsabilidade. Mas há um elemento de coerção nisso, e o próprio ato de reconhecimento da responsabilidade moral estabelece a responsabilidade mística e final dos ancestrais.

Por essa via os Tallensi podem aceitar sua responsabilidade pessoal pelo bem e pelo mal que lhes advêm ao longo de suas vidas sem se sentirem morbidamente culpados, sem terem que sofrer sanções morais ou religiosas. De fato, um aspecto surpreendente da reação Tale ao infortúnio é a ausência das expressões habituais de culpa, ainda que pesar, raiva, angústia, ao lado das emoções reconfortantes de esperança e alívio, sejam livremente demonstrados.

Expressando-o de outra maneira, poderíamos dizer que, quando as coisas vão mal, a pessoa envolvida admite ser em alguma medida responsável. Mas o costume lhe permite, ou mais, força-a a entender seus infortúnios como emanações de seus ancestrais. Já que são investidos de personalidade, podem ser apaziguados com palavras e atos, o que serve à restauração tanto da auto-confiança quanto da estima social da vítima.

O mecanismo desse processo é simples. Ao dedicar um santuário a seus ancestrais e assim trazê-los de volta a sua casa, o indivíduo ganha acesso direto a eles. Ao aceitar o dever de preservar e cuidar deles, ele converte sua hostilidade potencial em amizade potencial. Não se trata de uma relação contratual - como algumas autoridades querem ver no caso de Jó -, mas de uma relação de dependência e obrigação mútuas, ainda que uma relação delicada, sobrecarregada pela constante possibilidade de um revés devido à incomensurabilidade de condições e poderes entre as partes. $\mathrm{Na}$ verdade, ela não é mais que o reestabelecimento, num novo plano, da interdependência filio-paternal que a morte interrompera. Pois a morte é a culminação da clivagem entre gerações sucessivas que está na base da estrutura social Tale. No culto dos ancestrais, essa clivagem é transcendida e invertida, tanto conceitual quanto emocionalmente. Os pais, metamorfoseados em ancestrais, são devolvidos a um lugar na vida de seus filhos 
que reflete, simbolicamente, atributos decisivos da paternidade na vida real. Quando vivos, os pais exigem obediência, serviços econômicos, respeito (em casos especiais levado ao extremo de interditos obrigatôrios), além de confiança e afeição. Os ancestrais exigem serviços rituais, sacrifícios, reverência e observância dos tabus. Os pais vivos têm poder econômico e autoridade jurídica sobre seus filhos, bem como conhecimentos e habilidades que parecem desmedidamente grandes para seus filhos ainda crianças. Perpetuados em forma sobrenatural, esses atributos transformam-se em poder e autoridade místicos, ubiqüidade e onipotência. Por outro lado - e isto é igualmente importante -, os pais vivos não passam a vida a dar ordens e fazer exigências aos filhos; também cuidam deles com afeição e altruísmo. Do mesmo modo, também os ancestrais são benevolentes se convenientemente tratados e servidos. As coerções religiosas, ressentidas mais agudamente quando os ancestrais agem de modo punitivo, são a contrapartida das coerções da vida familiar, sentidas quando os pais impõem sua vontade. Quando o fazem, deverão seguramente contrariar seus filhos, e isso basta para despertar a suspeita de que estão irritados, ainda que não dêem mostras disso. No fundo, o mesmo conjunto de normas opera nas duas esferas - que aliás se interceptam, já que os poderes e status dos pais são respaldados pelas sanções do culto dos ancestrais.

Vale relembrar aqui que as relações pessoais normais entre pais e filhos são calorosas e amigáveis. Pais e filhos se confiam e se apóiam mutuamente, ao mesmo tempo em que observam cuidadosamente as restrições próprias a sua relação como membros de gerações sucessivas. Isso também se reflete no culto dos ancestrais. As orações pronunciadas durante os sacrifícios não são jamais degradantes: elas explicam as circunstâncias presentes, talvez expressem contrição, mas terminam com frases que, a despeito de toda sua forma persuasiva e conciliadora, sempre dão a entender que o sacrificante espera um retorno benevolente. E é esta a raiz da crença e da atitude de que, em última instância, os decretos dos ancestrais são sempre justos.

\section{DESTINO E A ESTRUTURA SOCIAL}

Estamos aparentemente longe de nosso contraste inicial entre Édipo e Jó. Em que sentido preciso podemos aplicar nossos paradigmas às instituições religiosas dos Tallensi? Face a tal questão, Frazer teria procurado por conexões em experiências humanas e processos mentais comuns aos grupos envolvidos. Como observei de saída, creio que ele estava certo em princípio, apesar de ter sido induzido ao erro pelos pressupostos que emprestou às ciências de seu tempo. São patentes os paralelos descritivos entre as crenças Tale e os paradigmas que propusemos; Frazer teria atentado primeiramente para elas, e não para seus sentidos subjacentes.

Frazer explicava o culto dos ancestrais a partir da crença na imortalidade da alma, conjugada ao medo dos mortos que lhe parecia virtualmente instintivo 
em toda a humanidade ${ }^{31}$. Uma explicação dessa espécie seria uma hipersimplificação risível se aplicada aos Tallensi ou a qualquer povo da África Ocidental. Os Tallensi possuem um culto dos ancestrais não porque temam os mortos - e de fato eles não os temem - ou porque creiam na imortalidade da alma - pois eles não têm tal noção -, mas porque sua estrutura social o exige. Em outras palavras, eles têm um corpo complexo e elaborado de crenças e práticas rituais que serve à perpetuação e à regulação do significado dos mortos nas vidas de seus descendentes. Cultuam seus ancestrais porque a ascendência ou, mais exatamente, a paternidade é o determinante decisivo e irredutível de toda a sua estrutura social. Não são o medo, a ignorância ou a superstição, mas sim os laços morais da relação filio-paternal que estão na origem do culto dos ancestrais entre os Tallensi.

Vimos que os conceitos jurídicos e rituais Tale distinguem com precisão vários elementos na constituição social e individual da pessoa, referindo-os aos diversos domínios da estrutura social em que agem. Notamos que o mero fato de nascer e sobreviver é o primeiro elemento; este fato recebe seu imprimatur ritual específico na forma de um espírito guardião. O espírito guardião serve para tornar claro e valorizar o próprio fato da nova vida individual, bem como sua dependência face aos cuidados paternos. É por dever sua vida aos pais, dizem os Tallensi, que cada pessoa mantém laços irrevogáveis e absolutos com eles. Em primeiro lugar, há os laços afetivos e morais que os Tallensi explicam com base no processo de formação dos filhos. A disciplina, autoridade, afeição e cuidados paternos criam reciprocamente dependência, obediência e amor respeitoso da parte dos filhos. Em seguida, há o componente jurídico do status na linhagem e da posição na trama de parentesco, adquiridos por nascimento numa certa família e constituindo um elemento de continuidade da estrutura social ao longo do tempo. $\mathrm{O}$ imprimatur ritual deste aspecto é a concepção dos ancestrais como soberanos e eternos, espelhando o conjunto do sistema de parentesco e descendência enquanto esquema fixo e eterno para a vida social dos indivíduos. Finalmente, há os laços criados pela sucessão das gerações. Os filhos devem suceder aos pais e as filhas às mães ao longo das gerações. Isto é expresso juridicamente por meio da herança e da sucessão e, ritualmente, no culto dos espíritos dos pais mortos.

Nesse contexto, o fato decisivo é a falta de alternativas para o indivíduo. A submissão a seus ancestrais simboliza sua encapsulação numa ordem social que não abre espaço para a alteração voluntária do status e da condição social. É o interesse comum, o propósito coletivo que prevalece.

Percebe-se que um indivíduo incuravelmente incapaz de se encaixar na estrutura social seria uma anomalia. Daí a grande importância de se dar reconhecimento ritual específico à individualidade de cada um: reconhece-se assim a necessidade de acomodar as realidades da vida na fixidez das normas estruturais, e é fácil ver como as noções de sorte, acaso, destino e mesmo, num linguajar mais 
sofisticado, a de predestinação podem ser usadas para reconciliar o determinismo do status jurídico e ritual, imposto pela estrutura social, com a variabilidade e imprevisibilidade dos ciclos de vida individuais. Se imaginarmos um gráfico da vida de uma pessoa entre os Tallensi, um eixo representaria seu movimento rumo à e no interior da estrutura social, e o outro representaria seu desenvolvimento pessoal, estando no ponto zero do gráfico sua concepção por tais e tais genitores.

É aqui que os conceitos edípicos ganham evidência. Eles reconhecem forças do desenvolvimento social e pessoal que não podem ser mudadas ou reguladas pela sociedade. A noção Tale de Destino Pré-natal designa o que, em linguagem mais abstrata, poderia ser descrito como uma disposição inata, que pode tender para o bem como para o mal. Os próprios Tallensi não têm, é claro, os recursos culturais necessários para analisar seu simbolismo religioso desta forma. Na verdade, se fossem capaz de fazê-lo, os símbolos seriam privados de sua força afetiva e expressiva. Somente o observador externo, observando o simbolismo em conexão com as outras instituições religiosas e no contexto da estrutura social, pode perceber seu sentido abstrato.

O que surpreende então são os critérios de identificação de um mau Destino Pré-natal: o fracasso - tão irremediável quanto involuntário - da vítima em preencher seus papéis sociais e em alcançar o desempenho considerado normal para alguém de seu status na estrutura social serve de prova da ação desse mau Destino Pré-natal. Não seria exagerado dizer que, para os Tallensi, reconhece-se uma pessoa atingida por esse Destino se ela se mostrar incapaz de incorporar-se ou de manter-se integrada à estrutura social; se, ao contrário, ela lograr fazê-lo, o sucesso será creditado a seu Bom Destino.

Por que, então, a vítima do Destino Pré-natal é dissociada da estrutura social? A doutrina e os hábitos rituais Tale afirmam que isso acontece porque, desde o instante de seu nascimento, ela rejeitou a sociedade e deu as costas às normas morais fundamentais, preferindo a morte à incorporação na trama de relações básicas com a família e os parentes. Essa não é uma rejeição consciente ou deliberada, já que a vítima não sabe de sua predisposição até que um adivinho a revele. Do ponto de vista da sociedade, a culpa recai sobre seus deséjos inatos e inescapáveis. Mas, do ponto de vista da vítima, sua condição lhe é imposta pela sociedade - como demonstram suas atitudes. Ela se crê rejeitada por seus parentes e ancestrais, já que todos os recursos da organização social, da habilidade terapêutica, do ritual e dos cuidados paternos foram incapazes de abrir-lhe um caminho para a normalidade social. A vítima tem razão na medida em que a autoridade soberana sobre sua vida reside na sociedade; a noção de Destino Pré-natal não é mais do que um último recurso: os responsáveis por seu bem-estar só lançam mão dela - com a sanção de um adivinho quando falham todos os apelos aos ancestrais. O que a noção simboliza é, portanto, o fracasso na incorporação à sociedade, isto é, à família, à linhagem e às relações de 
parentesco. Nos termos do desenvolvimento normal, trata-se de um fracasso na relação primordial entre pais e filhos, já que é por via dessa relação que os indivíduos se encaixam na socicdade e csta implanta ncles suas cxigências.

Estas considerações estruturais sugerem vários paralelos com a história de Édipo. Seu Destino é mau, e intervém em sua vida já quando ele é rejeitado pelos pais. Édipo só sobrevive porque é aceito por pais substitutos, mas se transforma de novo em pária quando seu Destino novamente o alcança e finalmente o aniquila por violar inadvertidamente as normas da relação filio-paternal. Sua tragédia pode ser descrita como a de um homem lutando cegamente por seu lugar legítimo na sociedade, primeiro como filho, depois como esposo, pai e cidadão, sempre contra a oposição invisível de um impulso inato a vingar-se de seus pais, sua esposa e seus filhos. Quando finalmente sucumbe a seu Destino, ele demonstra sua repulsa a si mesmo mutilando os próprios olhos e assim apagando suas relações com seus parentes e sua sociedade. Não será mais readmitido ao convívio social: Édipo morre no exílio, deixando este mundo mais como espectro que como homem normal.

Devemos entretanto ter em mente que a noção de Destino Pré-natal não é tão-somente um rótulo para uma classe de pessoas definível em termos estruturais, mas um conceito religioso associado a procedimentos rituais para acomodar, por meio de deslocamento simbólico, as tensões emocionais e afetivas geradas pelas antinomias em que se encontra o indivíduo afetado. Já vimos como a noção pode servir para exonerar tanto a sociedade quanto os indivíduos da responsabilidade última, fixando-a sobre os ancestrais e sobre um evento pré-natal (ou seja, présocial). Desse modo, o ônus da rejeição é transferido para o plano sobrenatural, e os sentimentos de impotência e depressão tornam-se toleráveis. Também no caso de Édipo o ônus recaía sobre o Destino; até mesmo seu pai e sua mãe tinham sido vítimas desse determinismo hereditário. Mas o papel atribuído à vontade humana é diferente na história de Édipo e no padrão mais simples dos Tallensi. Laio e Jocasta acreditavam poder frustrar o Destino abandonando seu filho; falharam, e os Tallensi o compreenderiam muito bem, pois não crêem que a prudência humana possa afastar forças sobrenaturais hostis. Segundo seu esquema de pensamento, apenas medidas rituais poderiam defendê-los de ameaças sobrenaturais.

A razão disso está no conceito Tale de causalidade mística, mencionado mais acima neste ensaio. Seu efeito se faz sentir nas crenças e práticas relacionadas ao processo de conversão para fins benéficos das potencialidades inatas do Destino. A prova de beneficência é a capacidade efetivamente demonstrada pelo indivíduo de alcançar as metas econômicas, jurídicas e sociais adequadas a alguém de determinado sexo, status e idade. Mas a beneficência duradoura só é assegurada se determinados ancestrais (normalmente paternos) aceitarem a responsabilidade sobrenatural por seu Destino. Podemos ver prontamente que esta é uma expressão, em símbolos e sanções religiosos, do ideal Tale dos pais (particularmente do pai) como seres que se empenham em cuidar de seus filhos pela vida inteira. Uma 
vez que os ancestrais-patronos são agentes dos ancestrais coletivos, seu papel é também o equivalente simbólico da incorporação do indivíduo e de seu ciclo de vida singular ao domínio político e jurídico da estrutura social. Conseqüentemente, ao submeter-se a seus ancestrais, o indivíduo está simultaneamente aceitando sua dependência frente a seus pais (a seu pai especialmente) e sua incorporação à sociedade. Esta é uma relação absoluta, isto é, sobrenaturalmente sancionada, na qual o dever de se pautar pelos axiomas morais básicos é assumido por todos como valor supremo. Estamos na situação oposta à de uma vítima de um mau Destino Pré-natal. Nos termos abstratos que estamos usando, diríamos que a adaptação das potencialidades individuais inatas às necessidades e aos valores da sociedade impede-as de se tornarem destrutivas e as dirige ao desenvolvimento social produtivo, à vida normal na sociedade.

Expondo o argumento de maneira ligeiramente diferente: se os pais fracassam em sua tarefa de formação dos filhos, a hostilidade latente de seus filhos contra eles prevalece - ao menos é o que se supõe - e acaba por destruir os laços entre eles. O mau Destino Pré-natal permite conceitualizar essa experiência. Por outro lado, se os pais cumprem sua tarefa, seu sucesso é prova de que usaram o poder e a autoridade de que a sociedade os investe com benevolência - em termos religiosos, com as bênçãos dos ancestrais. Ao mesmo tempo, o êxito mostra que seus filhos reagiram à disciplina, cuidados e afeição paternos com seu desenvolvimento rumo à maturidade; a aquiescência confiante a seus pais foi mais forte que o antagonismo latente. A noção de Bom Destino conceitualiza essa experiência e lhe fornece sanção e valor como força moral duradoura na vida do indivíduo. É neste ponto que as crenças Tale divergem inteiramente da história de Édipo: para ele não havia maneira de transformar o Fado em Destino benevolente. Estamos mais próximos da história de Jó.

Falando figurativamente, poderíamos dizer que a submissão aos ancestraispatronos transforma a predisposição edípica na redenção final de Jó. O drama da vida de Jó provém do fato de seu Deus o escolher para pôr à prova sua fidelidade, de modo comparável à maneira segundo a qual os ancestrais-patronos dos Tallensi escolhem seu protegido e testam continuamente sua fé através das exigências que lhe fazem. Esta é uma indicação entre muitas de que Jó não é jamais repudiado, aberta ou implicitamente, por seus próximos ou por seu Deus. As tribulações que ele suporta são de ordem diferente das que o Destino irrevogável causa a Édipo. Como sugeri de início, seus infortúnios podem bem ser comparados a uma forma severa, mas justa, de punição paternal, e é por isso que não são trágicos como os de Édipo, mas simplesmente patéticos (ainda que em escala cósmica). Na verdade, eles fazem parte da textura geral de sua relação com seus próximos e com seu Deus, no interior da qual ele goza de apreço e da qual ele jamais se afasta. É apenas no seio dessa relação que Deus, o superior, pode castigar Jó e este, o inferior, pode se defender com sua conduta e seus argumentos virtuosos. É verdade que no começo Jó se sente distanciado de seus próximos e 
perseguido injustamente por seu Deus, mas isso só ocorre porque ele confunde seu status e se crê com direito ao reconhecimento e à recompensa nos termos de seus próprios padrões de virtude e justiça. Os Tallensi não cairiam nesse erro em relação a seus ancestrais.

A salvação de Jó vem quando ele reconhece a onipotência de Deus como um fenômeno além do questionamento humano. Ele percebe que a submissão deve ser absoluta, pouco importa se corresponda ou não às normas de conduta virtuosa entre os homens. Esta submissão é a atitude de humildade filial e fé nos pais poderosos. Nessa relação é possível, e mesmo inevitável, que o inferior aceite todas as determinações do superior - sejam ou não de seu próprio interesse - como atos de justiça. No caso de Jó, a accitação faz suas tribulações parecerem meios para ele alcançar uma compreensão verdadeira da natureza de sua dependência frente a Deus e das obrigações daí decorrentes. É bem apropriado que, no fim, ele seja reconduzido não apenas aos favores de Deus, mas também à saúde, a seu status e posição social. Os Tallensi entenderiam muito bem a história, por analogia com seu culto dos ancestrais; para Édipo, não existia esse caminho de volta à normalidade.

\section{ReCAPitulação}

Para recapitular: a noção de mau Destino Pré-natal entre os Tallensi serve para identificar o fracasso irremediável de um indivíduo no desenvolvimento de suas potencialidades sociais plenas. Mais que isso, ela dá expressão simbólica ao sentido estrutural implícito de um tal fracasso enquanto indicador de um relacionamento filio-paternal malogrado. A possibilidade de que essa relação vá mal é uma ameaça para laços e sentimentos morais e afetivos fundamentais. Para afastála, entram em cena procedimentos rituais baseados na crença de que o mau Destino Pré-natal é em última instância suscetível de controle pelos antepassados, se eles assim o quiserem. Seguindo o raciocínio, os desafortunados devem ser aqueles infelizes que as instituições sociais, simbolizadas pelas figuras dos ancestrais, rejeitaram. O componente hostil da relação filio-paternal ganha realce e é expressado simbolicamente na imagem do mau Destino Pré-natal que finalmente destrói sua vítima.

A noção de Bom Destino, por outro lado, identifica simbolicamente o sucesso no desenvolvimento social rumo à completa incorporação à sociedade. Ela serve para tornar esse fato compreensível e para dar-lhe um selo de valor religioso como sinal implícito de uma relação filio-paternal normal e feliz. O pressuposto simbólico utilizado é o de que o Destino age dessa maneira se os ancestrais o absorvem e aprovam. Explicam-se assim as recompensas que dão testemunho do desenvolvimento bem-sucedido, ao mesmo tempo em que se fornece uma base para os procedimentos rituais que afastam os efeitos desmoralizantes das vicissitudes de cada vida sobre os laços e sentimentos morais e afetivos. Os afortunados são 
por conseguinte aqueles que, por um lado, tiveram a sorte de serem aceitos pelas instituições paternais simbolizadas no culto dos ancestrais e, por outro, são dotados de habilidade para manter com elas relações de confiança e apoio mútuos. $\mathrm{O}$ componente hostil da relação filio-paternal é suplantado pela atribuição aos ancestrais de um caráter predominantemente benévolo. Nesse contexto, o aspecto punitivo das figuras ancestrais tem função mais disciplinar que punitiva: é o instrumento de sua justiça e a medida de sua soberania, paralelas no plano religioso aos hábitos e formas da vida familiar que já descrevemos. Sentimentos individuais de culpa e angústia são eliminados através dos rituais estabelecidos de conciliação e expiação, que só funcionam porque se acredita que, além de punir a má conduta, os ancestrais são também justos e benevolentes a longo prazo.

Que podemos aprender com essa investigação restrita? A obra de Frazer é uma advertência contra generalizações fáceis a partir de paralelos entre costumes e crenças de sociedades profundamente diferentes. Entretanto, meu objetivo neste ensaio não foi o de encontrar paralelos, mas sim o de trazer à luz elementos básicos comuns às concepções religiosas que descrevi. E ao menos um elemento comum é patente. Todos os conceitos e crenças que examinamos são extrapolações religiosas de experiências geradas nas relações entre pais e filhos em sociedades organizadas sobre o parentesco e a descendência. Trata-se de extrapolações ampliadas e disfarçadas, e seu efeito é o de dotar os componentes decisivos da relação filio-paternal de realidade e representação externas, de âmbito social e não simplesmente do domínio dos pensamentos e da fantasia individuais. As concepções religiosas dos Tallensi exibem esse processo de forma direta. Pudemos descobrir as raízes dessas crenças no sistema familiar e observar como suas ramificações se espalham por toda a estrutura social. Podemos ver como se relaciona a esfera da família, onde os filhos são criados, à esfera da sociedade política, onde eles deverão levar suas vidas; e pudemos ver como a paternidade, de um lado, e a soberania da sociedade, de outro, são investidas de caráter sagrado. Édipo e Jó exprimem os elementos básicos desse tipo de sistema religioso: também eles são reflexos parcialmente disfarçados das instituições de parentesco e família. Só têm mais apelo para nossa imaginação e nossas emoções do que os dados pouco sofisticados da religião Tale por revestirem crenças e conceitos toscos com a rica panóplia do pensamento ético e das doutrinas metafísicas das culturas letradas. Mas o núcleo de crenças e atitudes fundamentais é o mesmo.

São essas então as áreas de experiência humana comum a que devemos referir nossos dados. Desde as especulações ousadas de Freud em Totem e tabu e da grande obra de Durkheim sobre As formas elementares da vida religiosa, os antropólogos sabem que as fontes da religião e do ritual estão nas relações de parentesco e na organização social. Tentei relacionar concepções religiosas específicas à importância, para a sociedade em questão, de absorver seus novos membros. Considerados apenas como superstições, as crenças no Destino e nos ancestrais 
(ou no Deus de Jó) parecem antitéticas. A primeira é a-moral, a segunda é moral ao máximo. Mas como observamos nas religiões da África Ocidental, elas são mais complementares que antitéticas. Ao menos no caso dos Tallensi, elas podem ser descritas como momentos conceituais suplementares de um aparato religioso para lidar com os compromissos que surgem para a sociedade e para seus membros com a entrada e a acomodação de cada novo membro ${ }^{32}$. Elas reconciliam as duas grandes alternativas na passagem arriscada do estado de dependência irrestrita da criança no colo da mãe ao estado de independência restrita de adulto e cidadão. É uma lei da natureza que alguns indivíduos devam fracassar, parcial ou completamente, na tarefa de se tornarem - e permanecerem - pessoas sociais. Esse fracasso gera uma situação difícil, que as crenças e rituais centrados na noção de Destino Prénatal (ou edípico) procuram interpretar, avaliar moralmente e controlar, em nome dos interesses da sociedade e do indivíduo. A maioria das pessoas acabará por ter êxito, mas só depois de passar por riscos imprevisíveis e recompensas precárias. Para dar sentido e valor moral absoluto a esta experiência, os Tallensi invocam figuras sobrenaturais personificadas, moldadas como pais glorificados que intervêm favoravelmente na vida do indivíduo e da sociedade. A imagem resultante, a do Bom Destino, é essencialmente uma versão mais simples do Deus de Jó.

Talvez o conceito de Destino Pré-natal possa servir para designar tendências de origem orgânica ou experiências muito precoces de dependência infantil. É muito interessante notar que, em muitas sociedades, essas tendências parecem ser reconhecidas intuitivamente, e compreendidas como resistências inconscientes à relação normal de paternidade. O culto dos ancestrais ou de certas divindades, por outro lado, pressupõe o triunfo da paternidade, e assim afirma a supremacia das normas morais derivadas da sociedade sobre o perigoso egoísmo da infância.

\section{Notas}

1 J. G. Frazer, Psyche's task (1923), p. 56.

2 Êxodo 4:25.

3 Frazer, Folklore in the old testament (edição de 1918), vol. 1, p. 101.

4 Ibid., vol. 2, p. 438-46.

5 Cf. Meyer Fortes, "Analysis and description in social anthropology", Advancement of Science 38 (1953).

6 Cf. F. M. Cornford, From religion to philosophy (1912), pp. 126ss; D. W. Lucas, The Greek Tragic Poets (1950), pp. 133ss; J. Pedersen, Israel: Its Life and Culture (1926), 2 vols., pp. 358ss. 
7 Lucas, op. cit., pp. 133ss.

8 Por exemplo, F. M. Cornford, op. cit.; E. R. Dodds, The Greeks and the irrational (1951); H. J. Róse, verbete "Destino" na Encyclopedia Britannica, $14^{a}$ edição.

9 Dodds, op. cit., p. 42.

10 Cf. E. E. Evans-Pritchard, Witchcraft, oracles and magic among the Azande (1937).

11 Pedersen, op. cit., pp. 358ss.

12 Jó x. 2.

13 Jó xx. 5.

14 Jó xl. 8.

15 Cf. os artigos no verbete "Destino", no vol. 5 da Encyclopedia of Religion and Ethics de Hastings.

16 W. R. Bascom, "Social status, wealth and individual differences among the Yoruba", American Anthropologist 53, n 4 (1951).

17 Cf. R. E. Bradbury, The Benin Kingdom (Ethnographic Survey of Africa, parte 13, 1957).

18 M. J. Herskovits, Dahomey (1938), vol. 2, especialmente o cap. 30. Ver também B. Maupoil, La Géomancie dans l'ancienne Côte des Esclaves (1943).

19 Herskovits, op. cit., vol. 2, p. 222.

20 Herskovits, op. cit., vol. 1, cap. 11.

21 Os povos Mole-Dagbane da região do Volta. Cf. Meyer Fortes, The dynamics of clanship among the Tallensi (1945); The web of Kinship among the Tallensi (1949).

22 B. Malinowski, "Magic, science and religion", in Science, Religion and Reality, org. por J. Needham (1925).

23 M. Fortes, op. cit. $(1945,1949)$

24 Cf. Fortes, Dynamics of clanship, pp. 52ss.

25 Cf. Fortes, The Web of clanship, pp. 52ss.

26 Há um termo específico (sag) na linguagem ritual para o ato de aceitar a (ou antes con- 
sentir na) as ordens dos ancestrais, e é digno de nota que a mesma palavra é usada para descrever a aâáo de um dos pais, de um ancião ou de um ancestral que respondem com benevolência à conduta de um dependente seu.

27 É este o atributo que distingue os ancestrais de outras entidades sobrenaturais na maioria dos sistemas religiosos que incluem o culto dos ancestrais; cf. Monica Wilson, Rituals of kinship among the Nyakusa (1956), para uma análise admirável dessa concepções num povo da África Oriental.

28 Cf. Fortes, Wwb of Kinship, pp. 32ss. Nesse aspecto os Tallensi são muito diferentes das outras sociedades da África Ocidental a que me referi.

29 Cf. Fortes, Dynamics of clanship, capítulo 8.

30 Como no caso clássico dos Azande (cf. E. E. Evans-Pritchard, Witchcraft, oracles and magic among the Azande). Cf. ainda Monica Wilson, op. cit., além de uma discussão esclarecedora sobre o mesmo ponto no artigo Witches, do Prof. P. Mayer (Rhodes University, Grahamstown, 1957).

31 Esta é uma hipótese tipicamente frazeriana, longa e prolixamente exposta em The belief in immortality (1913); cf. especialmente vol. 1, pp. 23ss, e vol. 2, pp. 57ss. Ela também ocorre em outros contextos, por exemplo em Totemism and Exogamy (1910), vol. 4, p. 32.

32 Cf. Jack Goody (ed.), The developmental cycle in domestic groups (Cambridge Papers in Social Anthropology, $\left.\mathrm{n}^{\circ} 1,1958\right)$, para uma análise de outros aspectos deste problema. 


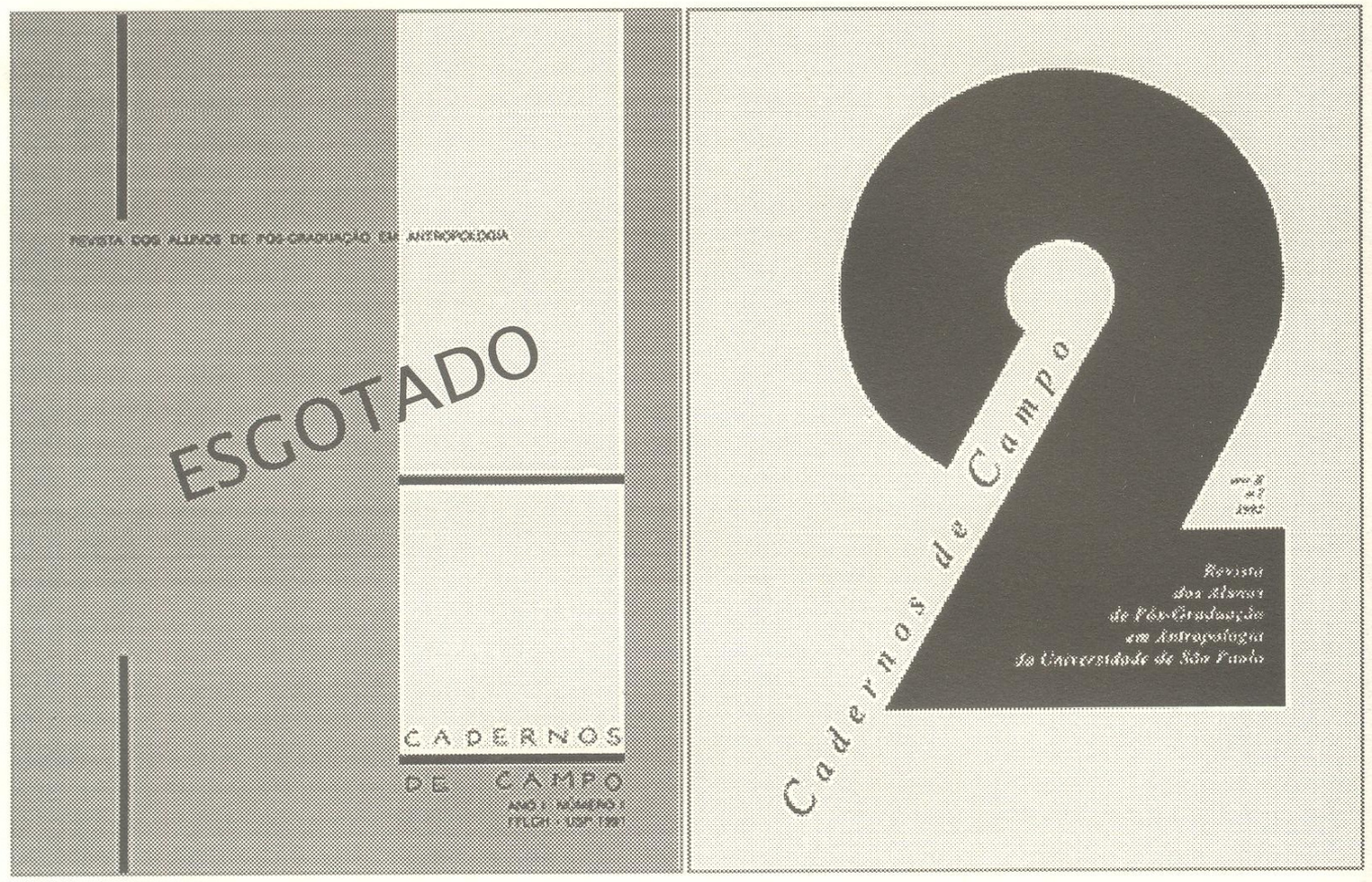

Revista dos alunos de Pós-Graduação em Antropologia Social da USP

Envie seu pedido com cheque nominal a Gabriel C. Barbosa para:

Cadernos de Campo - Caixa Postal 2530 CEP 05508-900

Cidade Universitária - São Paulo-SP

Preço do exemplar: $\mathrm{R} \$ 10,00$

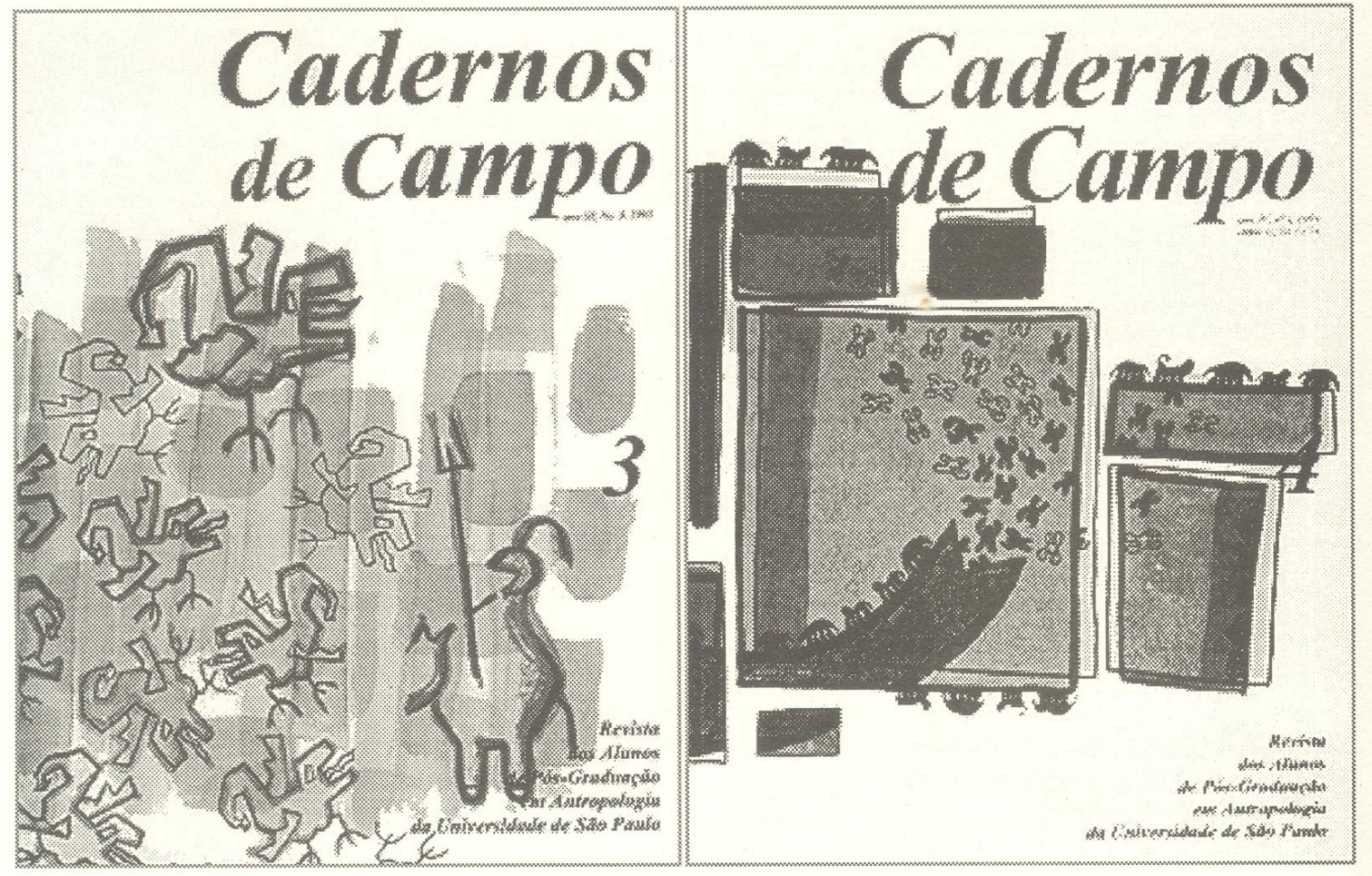

